Portland State University

PDXScholar

Environmental Science and Management

Professional Master's Project Reports

Spring 2014

\title{
The Effectiveness of Forest Collaborative Groups at Reducing the Likelihood of Project Appeals and Objections in Eastern Oregon
}

Brent M. Summers

Portland State University

Follow this and additional works at: https://pdxscholar.library.pdx.edu/mem_gradprojects

Part of the Forest Management Commons, and the Natural Resources Management and Policy Commons

Let us know how access to this document benefits you.

\section{Recommended Citation}

Summers, Brent M., "The Effectiveness of Forest Collaborative Groups at Reducing the Likelihood of Project Appeals and Objections in Eastern Oregon" (2014). Environmental Science and Management Professional Master's Project Reports. 41.

https://pdxscholar.library.pdx.edu/mem_gradprojects/41

https://doi.org/10.15760/mem.50

This Project is brought to you for free and open access. It has been accepted for inclusion in Environmental Science and Management Professional Master's Project Reports by an authorized administrator of PDXScholar. Please contact us if we can make this document more accessible: pdxscholar@pdx.edu. 
The Effectiveness of Forest Collaborative Groups at Reducing the Likelihood of Project Appeals and Objections in Eastern Oregon

\author{
By \\ Brent M. Summers \\ Committee: \\ Dr. Robert Scheller \\ Committee Chair \\ ESM Department, Portland State University \\ Dr. Nathan Poage \\ Community Partner \\ Clackamas Stewardship Partners (formally) \\ Dr. Max Nielsen-Pincus \\ ESM Department, Portland State University
}

Submitted June 13, 2014 to the Environmental Science and Management

Department at Portland State University in partial fulfillment of the Masters of Environmental Management degree. 


\section{Table of Contents}

$\begin{array}{lr}\text { Acknowledgements } & 04\end{array}$

$\begin{array}{lr}\text { Abstract } & 05\end{array}$

$\begin{array}{ll}\text { Introduction } & 07\end{array}$

$\begin{array}{ll}\text { Methods } & 13\end{array}$

Study Area - Eastern Oregon and Forest Collaborative Groups $\quad 13$

Data Acquisition and Description 15

$\begin{array}{ll}\text { Data Formatting } & 17\end{array}$

$\begin{array}{ll}\text { Data Analysis - Odds Ratio Analysis } & 18\end{array}$

$\begin{array}{lr}\text { Results } & 20\end{array}$

$\begin{array}{lr}\text { Summary Information } & 20\end{array}$

Odds Ratio Results $\quad 21$

$\begin{array}{lr}\text { Discussion and Conclusion } & 22\end{array}$

$\begin{array}{lr}\text { Management Implications } & 28\end{array}$

$\begin{array}{ll}\text { Future Research } & 31\end{array}$

$\begin{array}{ll}\text { Conclusion } & 34\end{array}$

$\begin{array}{ll}\text { Figures } & 35\end{array}$

$\begin{array}{ll}\text { Tables } & 40\end{array}$

$\begin{array}{ll}\text { References } & 46\end{array}$

Appendix A - Two-by-Two Contingency Tables 50

Appendix B - Summary Tables and Graphs 


\section{List of Figures}

$\begin{array}{ll}\text { Figure 1 - Federal Project Process } & 35\end{array}$

Figure 2 - Oregon National Forest and Forest Collaborative Group Location 36

Figure 3 - Timeline of Forest Collaborative Group Establishment 37

Figure 4-Odds Ratio Results for National Forests and Eastern Oregon 38

Figure 5 - Odds Ratio Results for Eastern Oregon by Year, 2006 - 2012 


\section{List of Tables}

Table 1 - Forest Collaborative Group Summary $\quad 40$

Table 2 - NEPA Document Summary Information for Eastern Oregon 41

Table 3 - Forest Collaborative Group NEPA Documents Summary by National Forest 42

Table 4 - Odds Ratio Results for National Forests and Eastern Oregon 43

Table 5 - NEPA Document Summary Information for Eastern Oregon by Year, 2006 - 201244

Table 6 - Odds Ratio Results for Eastern Oregon by Year, 2006 - 201245 


\section{Acknowledgements}

I'd like to acknowledge and thank many people who have helped me complete my research and this project. First I'd like to thank my committee of Drs. Robert Scheller, Nathan Poage, and Max NielsenPincus for their assistance and guidance from project conception to completion. Second l'd like to thank the people I spoke with at each Forest Collaborative Group for their comments and help. I'd like to thank all my fellow lab members in the Dynamic Ecosystems and Landscapes Lab at Portland State for their support and help for the last two years. Finally, l'd like to thank my family, especially my wife Gloria Summers, and friends for their continued support these past two years. Thank you for always asking me to explain in simpler terms or justify why I wanted to do a certain type of analysis; you all helped prepare me for the final presentation and manuscript by forcing me to think about my research and explain it even when I thought I had already done an adequate job. 


\begin{abstract}
Collaborative planning has been used as a tool to address wicked natural resource conflicts and engage those affected by federal land management agency decisions. The United States Forest Service (USFS) is mandated by law to involve the public on project-level planning. In Oregon, Forest Collaborative Groups have been engaging with the USFS to involve stakeholders who are concerned with the activities on National Forests. It is widely believed that these groups are reducing project-level appeals and objections (appeals); however, there is no empirical evidence to validate these beliefs. National Environmental Protect Act (NEPA) document data were collected from the USFS for 2006 to 2012. Data from harvesting and fuels treatment activities were selected for six National Forests in central and eastern Oregon. These projects are of concern due to the large cumulative effect they have on National Forests ecosystems and the surrounding communities. Potential cumulative effects can divide stakeholders, causing project-level appeals. To determine Forest Collaborative Group involvement, NEPA document lists were sent to each of the ten groups. The collaborative groups were asked to note if their group was involved in the planning process. Responses were compiled and odds ratio analysis was used to determine the likelihood of an appeal of a NEPA document over time. The results for eastern Oregon suggest that projects that have input from a Forest Collaborative Group are less likely to be appealed. Individually, the Deschutes, Ochoco, and Wallowa-Whitman results suggest the same. The Fremont-Winema and Malheur results suggest projects without collaborative group input are less likely to be appealed. There are many other factors that could be affecting appeal levels however. For example, broadening the definition of collaboration would most likely increase the number of NEPA documents with collaborative
\end{abstract}


input and could decrease the likelihood of collaborative projects being appealed. Timber sale and fuel treatment projects are historically controversial and may be predisposed to be appealed or objected. In addition, external appeals and objections can stall a proposed project even where local support for a project exists. Finally, the Forest Collaborative Groups may be limited in their capacity to engage on multiple projects at any one time. Management implications of my research include finding a way to expand Forest Collaborative Group's capacity to engage on multiple projects, continue to promote engagement between Forest Collaborative Groups and the USFS, allow for more controversial projects to be brought to the Forest Collaborative Groups, and financial support from the State of Oregon modeled after the Oregon Plan for Salmon and Watersheds should be set up to help the Forest Collaborative Groups expand their capacity to engage with the USFS on projects.

Keywords: United States Forest Service, NEPA, National Environmental Policy Act, forest collaborative groups, collaborative, appeals, objections 


\section{Introduction}

Federal forest management has long been a strongly debated topic in the American West. The National Forest System, owned and managed by the Federal government, makes up a large portion of the forest land located in the American West. The National Forest System and the management plans and activities are administered by the United States Department of Agriculture Forest Service (USFS). These management plans and activities can come into conflict with the ideologies of surrounding communities. In addition to the surrounding communities, there are other groups that have interest in the National Forests and the way the USFS managed those forests. All these different groups are known as stakeholders who have an interest for one reason or another (economic, recreation, spiritual, etc.) in the way the USFS is managing the National Forest System. Due to there being many different interests and thus ideologies, conflict can arise over what is the correct way to manage the National Forest System. This conflict in forest management represents a classic wicked problem (Rittel \& Webber 1973; Allen \& Gould 1986) with no clear and optimal solution. With the presence of many different opinions and ideologies, forest management solutions are usually considered to be good or bad instead of right or wrong. In addition, the often chosen solution is the solution that is more emotionally fulfilling, not necessarily the best scientifically (Allen \& Gould 1986). This characteristic of wicked problems can cause differing opinions among USFS employees and stakeholders depending on who is viewing the management solutions (Rittel \& Webber 1973). Collaboration has emerged as an approach to help deal with the wickedness of forest management. Allen and Gould (1986) state that wicked problems are created by people yet are also solved by people. 
The USFS has a long history of using collaborative efforts in their projects, planning, and management activities. With the passage of the Multiple Use Sustained Yield Act in 1960, the USFS was obliged to balance conflicting interests of stakeholders (Leach 2006). The National Environmental Policy Act (NEPA) of 1970 allowed for the public to comment on draft and final environmental impact analysis reports prior to a final decision being published. In 1976 the National Forest Management Act was enacted which explained how exactly the USFS should include the public in relation to National Forest plans. Although the National Forest Management Act only applied to forest plan developments and revisions, NEPA allowed for much greater public involvement in federal agency activities since the NEPA process is undertaken anytime federal action is taken. While public involvement has been mandated by the passage of these laws, Carr et al. (1998) note that private citizens have continued to request the "right to [meaningful participation] in the management of public lands."

Gray (1989) defines collaborative planning as "a collective process for resolving conflicts and advancing shared visions involving a set of diverse stakeholders." Carr et al. (1998) expands on this definition by noting that collaborative planning involves "face-to-face dialogue, mutual learning, and voluntary participation." Many studies have presented the benefits, obstacles, and suspected future of collaborative planning in natural resource planning. Some studies (Selin et al. 1997, Carr et al. 1998, Schuett et al. 1998, Leach 2006) suggest a long standing use of collaborative planning by the USFS and an overall positive trend in the use of collaborative planning on National Forests. Selin et al. (1997) and Carr et al. (1998) found that USFS 
employees believed that collaborative planning efforts are well engrained into project-level planning and management yet lacking in strategic, broad scope planning. Schuett et al. (2001) found that participation in natural resource planning by stakeholders is becoming an accepted method for planning. Benefits of collaborative planning include increase in shared information, mutual learning, building relationships, trust formation and cementation, improving efficiency, and reducing appeals, litigation, and court costs (Selin et al. 1997, Schuett et al. 1998, Carr et al. 1998). Support for the use of collaborative planning is generally greatest among those actually involved in the process and perceived support decreases when looking up the organizational structure of the USFS (Selin et al. 1997, Schuett et al. 1998, Carr et al. 1998).

As noted above, collaborative planning is believed to be well established and used at the project-level scale. Currently there are two laws that affect project-level activities. These laws are the NEPA and the Healthy Forests Restoration Act (HFRA). The NEPA is procedural and designed to examine and inform about environmental impacts a proposed project may have. The act applies to all activities undertaken by federal agencies or projects that are federally funded. Due to this requirement, NEPA has become fully entrenched in USFS activities (Selin et al. 1997, Stern et al. 2010). Examples that would require environmental impact review under NEPA include timber sales, road building and decommissioning, restoration work, among others. Projects such as these are subject to the project-level post-decision appeals process (36 CFR 215) where an appeal is made after a final decision is issued by the USFS. Since the appeals come after a final decision has been issued, appeals must be resolved before the USFS can begin project implementation. Appeals can be resolved with either affirmation of the USFS's 
final decision, affirmation of the final decision with instructions to the USFS employee who signed the final decision, or the USFS can withdraw their final decision. Once all appeals have been resolved the last course of action a stakeholder can take to stop a project is to sue the USFS.

The HFRA was passed in 2003 and was designed to expedite hazardous fuels treatment project implementation by allowing for the environmental impact analysis document for the proposed project to be developed using a streamlined NEPA process. The passage also created a new project regulation specifically for hazardous fuels treatment projects. Projects with the HFRA specific regulations (36 CFR 218) are subject to a pre-decisional objection period. Unlike postdecisional appeals, pre-decisional objections occur before a final decision is issued the USFS. Once all objections have been resolved, the USFS issues a final decision and can move to project implementation. Much like the post-decisional appeals process, pre-decisional objections can affirm the USFS's final environmental document, affirm with instructions, or lead to the USFS withdrawing the final environmental document. After all objections are resolved, a stakeholder can only sue the USFS if they believe the project still should not be implemented. Postdecisional appeals are not allowed for projects with the HFRA regulation (36 CFR 218) because the pre-decisional objection process replaced the post-decisional appeals process when the HFRA was passed.

The process for NEPA and HFRA both laws is the same until the final review phase of the environmental impact analysis document (Figure 1). At this point the laws diverge and take 
different steps to agency implementation of the proposed project. Project environmental impact analysis documents with the project-level NEPA regulation are issued a Record of Decision after final review and can proceed to agency implementation unless an appeal is brought forth. Environmental impact analysis documents conducted under the HFRA process must go through a pre-decisional objection period before a Record of Decision can be issued. During the objection period, private citizens and other stakeholder groups can object to the proposed hazardous fuels treatment project but must address specific comments they made earlier in the review process. After the objection period has ended and all objections have been resolved, the USFS can move to project implementation. This research looks at both postdecisional appeals and pre-decisional objections because both can stall projects and lead to a delay in project implementation.

Two of the most controversial types of these projects are timber sales and hazardous fuels treatments. Timber sale projects have been the greatest appealed project type across all USFS Regions (Teich et al. 2004). Projects given the 36 CFR 215 designation were also found to be the most appealed projects (Teich et al. 2004). Due to the mandatory NEPA public review period, stakeholders can review the proposed action and appeal that action if desired (Germain et al. 2001). The nature of these types of projects is inherently controversial and attracts stakeholders during the project scoping process.

In Oregon, Forest Collaborative Groups (FCGs) have been increasingly working with the USFS in order to get different types of projects, such as timber sale and fuel treatments, agreeded upon 
and implemented. Establishment of FCGs in Oregon started in 1992 with the Applegate group in southwest Oregon. Eighteen of the twenty-three forest collaborative groups detailed in the Oregon Forest Collaboratives Statewide Inventory established after 2003 (Oregon Solutions 2013). While it is generally believed FCGs are having an effect on appeals rates and reducing litigation when collaborating with the USFS (Oregon Solutions 2013), there is no empirical evidence to date. Selin et al. (1997) and Carr et al. (1998) found similar results with USFS employees believing collaboration reduces project-level appeals and litigation. In their November 2012 report, the Federal Forest Advisory Committee - Implementation Working Group noted that FGCs need to be examined to determine their value and should be done by analyzing projects FGCs have been involved with. Oregon Solutions (2013) found that many working in FCGs believe the groups are reducing litigation cost for the USFS. Although all the FCGs have different mission statements and/or goals, they all revolve around the idea of restoring natural forest resilience at a landscape scale by using a community-based approach.

My project will examine the impact FCGs are having on timber sales and hazardous fuels treatment projects in eastern Oregon. The overarching goal of this project is to see how the collaboration is affecting USFS forest management by asking FCGs NEPA documents for timber sale and hazardous fuels treatment projects are less likely to be appealed or objected (appealed) when compared to non-FCGs NEPA documents for the same project types. NEPA document data from years 2006 to 2012 was examined to determine how many projects were appealed. Projects will be included based on the activity and purpose codes found within the NEPA document data to make sure only harvesting/timber sales and hazardous fuels treatment 
projects are being included. The FCGs were asked to note projects where they had engaged the USFS during the scoping phase. Since I'm trying to determine likelihood of an outcome (not appealed), odds ratio analysis was conducted for each of the individual National Forests and eastern Oregon to determine the impact the FCGs are having, if any, on appeals over time.

\section{Methods}

Study Area - Eastern Oregon and Forest Collaborative Groups

The study area for this project encompasses six USFS National Forests located in central and eastern Oregon (eastern Oregon, Figure 2). This project only focuses on land owned by the USFS and excludes all privately, state and other federally owned land. For eastern Oregon these National Forests make up the majority of the forest landscape, approximately 9.9 million acres of forest land. The National Forests included in the project are the Deschutes National Forest, the Fremont-Winema National Forest, the Malheur National Forest, the Ochoco National Forest, the Umatilla National Forest, and the Wallowa-Whitman National Forest (Figure 2). These six National Forests share common forest types that are distinctly different from forest types found in the National Forests west of the Cascade Mountains. Coupling this difference in forest types with the jurisdiction of the Northwest Forest Plan, which adds another layer of complexity to an already complex situation, National Forests west of the Cascade Mountains were not included in this research. The National Forests not included are the Mt. Hood National Forest, Rogue River-Siskiyou National Forest, the Siuslaw National Forest, the Umpqua National Forest, and the Willamette National Forest. 
The National Forests east of the Cascade Mountains are much drier than National Forests west of the Cascade Mountains due to the rain shadow effect of the Cascade Mountains. The decrease in precipitation leads to the presence of dry-zone forest types including mixed conifer and pine dominated types. Tree species such as ponderosa pine, lodgepole pine, western larch, and western juniper make up the dominate tree species in eastern Oregon. Fuel levels in the eastern Oregon National Forests are also at a much higher level currently than historical conditions. Carroll et al. (2007) note that forest stands are currently very homogeneous and dense compared to historical conditions. Additionally, Carroll et al. (2007) note that the denseness of stands has led to an increase in shade tolerant species not normally found in such abundance in the forests and ladder fuels that have accumulated in the understory. Fire suppression in the area dating back to the early 1900s has contributed to this change in forest structure (Carroll et al. 2007). The decline in federal timber harvest most likely has also contributed to a rise in fuel levels as trees that would originally be harvested for forest products were left to grow and add to the understory. This addition to the understory is worrisome because it provides ladder fuels that can cause catastrophic crown fires which may become more frequent as climate change shifts eastern Oregon into a drier climate.

Like much of the American west, eastern Oregon has a low population with Bend being the largest city. Eastern Oregon is populated with smaller towns and communities that have historically been dependent on natural resource extraction for economic prosperity. Although rural, many of these communities are made up of stakeholders with varying ideologies and opinions on how the USFS should manage the National Forests. Carroll et al. (2007) note that 
stakeholders on both sides of the Federal forest management issue can find grievances with the opposing side. The reduction in Federal timber harvest has had a great impact on these rural communities by causing sawmill closures and fewer timber sales being put to bid.

Located within the study area are ten FCGs spread over the six National Forests (Figure 2). The FCGs range in age and geographic extent in which they are interested in (Tables 1). Two of the FCGs were established in the mid to late 1990s, three in the first decade of the 2000s, and five since 2010 (Figure 3, Table 1). These FCGs are composed of stakeholders ranging from nonprofit groups (environmental, conservation, professional associations), private industry, local municipalities, tribal organizations, and state and federal agencies (Oregon Solutions 2013). The geographic extent to which these FCGs are interested in varies by group (Table 1). Some of the FCGs restrict themselves to Oregon county lines (e.g. the Blue Mountains Forest Partners focuses on portions of the Malheur National Forest that intersects with Grant and Harney counties) while others focus on entire National Forests (e.g. the Umatilla Forest Collaborative Group focuses on the entire Umatilla National Forest). The Central Oregon Partnership for Wildfire Risk Reduction is the only FCG that spans two compete National Forests, the Deschutes and the Ochoco.

\section{Data Acquisition and Description}

The NEPA data was collected from the Planning, Appeals, and Litigation System (PALS) database from the USFS in February of 2013. The dataset included all of Region 6 (Oregon and Washington) and full calendar years 2006 to 2012. The PALS data also included information 
pertaining to appeals, objections, and litigation relating to the listed NEPA documents. The litigation information was not used in this study because I only analyzes appeals and objections not projects that went all the way to litigation.

Each NEPA record includes the proposed activities and purpose codes. There are 49 different Activity Codes such as travel management, grazing authorizations, timber sales (two types: green and salvage), various vegetation management activities, fuel treatments, land use adjustments, land purchases/exchanges, road improvement/construction, among others. In addition to the Activity Codes there are 18 Purpose Codes. Some examples of Purpose Codes are land management planning, forest products, vegetation management, fuels management, road management, land acquisition, and research.

Data from a second USFS database, Forest Activities (FACTS), was obtained in December of 2013 for each of the National Forests in eastern Oregon. The FACTS data includes all activities that occur for a project that has a completed NEPA document and how those activities have progressed. The data also includes administrative information such as fiscal year the activities were planed and accomplished, number of units per activity planned and accomplished, and administrative information (region, forest, and district codes). The FACTS database is related to the PALS database through a unique identification number (the Project Number in PALS and the NEPA Project ID in FACTS). 


\section{Data Selection}

The PALS data needed to be condensed to just eastern Oregon instead of all of Region $6 . \quad$ I sorted the projects by National Forest using the "LMU_Forest_Level" column and then deleted all non-relevant records outside of the six eastern Oregon National Forests. Next, I narrowed down the records to only those that indicated timber sale or fuel treatment activities and purposes by looking at the Activity and Purpose Codes for each NEPA document record. The Activity Codes timber sales green (TS), timber sales salvage (SS) and fuels treatments nonactivity fuels (FN) were used as indicators of timber sale and fuels treatment activities. The Purpose Codes forest products (TM), vegetation management non-forest products (VM), and fuels management (HF) were used as well. For a particular NEPA document to be included in this study it needed to have at least one of these Activity or Purpose Codes included in it.

Next, a more in-depth filtering was done on the NEPA document records. I used the FACTS database to cross check which activities were being carried out in relation to each NEPA document to confirm that all the NEPA document records were for projects that actually contained harvesting and fuels treatment activities. If a particular NEPA document did not include any harvesting, thinning, or fuel treatments by cutting that record was removed. NEPA record titles were also used to determine if a document needed to be looked at in more detail. Prescribed burn documents were coded with FN Activity and HF Purpose Codes and were included in the initial list for each National Forest. After cross checking with the FACTS data, all prescribed burn NEPA documents were removed from the National Forest lists as they did not include any cutting or thinning activities. 
After filtering the PALS data to only include records with timber sale or fuel treatment projects, each National Forest was separated into its own list. These individual National Forest lists were used to create lists of NEPA project names that the ten FCGs may have been involved with. The FCG lists were made up of NEPA projects that had only occurred since the year of the FCG establishment forward. For example, the list sent to the Blue Mountains Forest Partners was from calendar year 2008 to 2012 since the Blue Mountains Forest Partners established in 2008. For FCGs that established before 2006, a list was sent containing all possible NEPA project names from calendar year 2006 to 2012 . After compiling list for each FCG, the lists were emailed to the representative contact found in the Oregon Forest Collaboratives: Statewide Inventory 2013 (Oregon Solutions 2013). If a contact was out of date, I asked for an updated representative from the original. The FCG representative was asked to indicate "yes" or "no" if NEPA projects were collaborative in nature (i.e. the FCG was engaged in the planning of the document). Responses were compiled into a master list as well as kept into individual National Forests.

\section{Data Analysis - Odds Raito Analysis}

To determine the likelihood of an appeal, the odds ratio was calculated for each of the National Forests and eastern Oregon as a region. The eastern Oregon region was the combined list of all the National Forests. Odds ratio values were also calculated for eastern Oregon on a year by year basis from 2006 to 2012. To calculate odds ratio, two-by-two contingency tables were set up for each of the National Forests, eastern Oregon, and for eastern Oregon for each year from 
2006 to 2012 (Appendix A). The treatments (rows) were Non-Forest Collaborative Group and Forest Collaborative Group. NEPA projects were coded as FCG and non-FCG based upon the responses provided from the FCG representatives. The two possible outcomes (columns) were "Not Appealed/Objected" and "Appeal/Objected." The PALS data was used to code appealed NEPA projects. The PALS data did not include information on objections. To code objections, I accessed the USFS Pre-Decisional Objection Responses for R6 - Pacific Northwest Region website (Forest Service Objection Responses for R6 2014). Using this website, I was able to fill in the PALS data when an objection had occurred.

There were two instances when two-by-two contingency tables could not be constructed. The Umatilla National Forest responses were not included in the eastern Oregon table because there were no FCG NEPA documents that occurred during the study timeframe. Odds ratio analysis was also not performed on the Umatilla for the same reason. The year 2011 also did not include any FCG NEPA documents and thus odds ratio was not run on the eastern Oregon 2011 year as well.

To account for the small sample size, log odds ratio analysis was initially performed. The resulting log odds ratio values were then transformed using the exponential function $\left(\mathrm{e}^{\mathrm{x}}\right)$ to get the final odds ratio values. It was decided to convert to odds ratio values because it is easier to communicate and understand odds ratio values as opposed to log odds ratio values. There are three different conclusions of odds ratio analysis that can be formed depending on the odds ratio value that is returned from the analysis. If the odds ratio value is returned as 1 , there is a 
fifty-fifty likelihood of a NEPA document being appealed regardless if has gone through a FCG or not. An odds ratio value above 1 indicates that Non-Forest Collaborative Group NEPA documents are less likely to be appealed. Finally, an odds ratio value below 1 indicates that FCG NEPA documents are less likely to be appealed. The log odds ratio values were calculated and transform into odds ratio values using the statistical software program R v3.0.1 ( $R$ Core Team, 2013) and the R package vcd v1.3-1 (Meyer et al. 2013). Confidence intervals for each log odds ratio value were calculated at $90 \%$. These $90 \%$ confidence intervals were transformed with the exponential function $\left(\mathrm{e}^{\mathrm{x}}\right)$ to give $90 \%$ confidence intervals for the odds ratios values.

\section{$\underline{\text { Results }}$}

\section{Summary Information}

Reducing the PALS data to the study area resulted in a total of 395 projects for all project types (including timber sale and fuel treatments). Of the 395 NEPA documents, 202 were for timber sales and/or fuel treatments. The NEPA documents ranged from a low of 23 on the Ochoco National Forest to a high of 41 on the Deschutes National Forest (Table 2). The total number of appeals for eastern Oregon was 98 with timber sale and fuel treatment NEPA documents accounting for 67 of those 98 appeals and objections. Five out of the six National Forests have a FCG that had participated in the NEPA scoping process (Table 3). The only National Forest with a FCG that had not participated in the NEPA scoping process was the Umatilla (the Umatilla Forest Collaborative Group was not established until 2011). From 2006 to 2012, all except 2011 had at least one NEPA document that a FCG had participated in. 
Over the seven year timeframe there were 30 NEPA documents that the FCGs noted they had participated in. The Wallowa-Whitman National Forest had eleven of the NEPA documents that had FCG participation. The Fremont-Winema National Forest had the second highest total with 9, followed by the Malheur National Forest with 5 (Table 3). Eight of the 30 FCG NEPA documents were appealed. The Fremont-Winema National Forest and Malheur National Forest each had three appeals and the Deschutes National Forest and Wallowa-Whitman National Forest each had one (Table 3).

Looking at the annual breakdown of projects for eastern Oregon from 2006 to 2012, it was found that 2008 had the greatest number of timber sale and fuel treatment projects with 56 and 2011 had the least with seven (Table 5). The greatest number of appeals/objections occurred in 2007 (16) with the least being 2011 (4) (Table 5). The years 2008 and 2009 had the highest occurrence of FCG timber sale and fuel treatment project types with seven and 2011 the lowest with zero. Three years $(2006,2011$, and 2012) tied for the lowest number of FCG NEPA document appeals with zero and 2010 had to highest number of appeals with three (Table 5). Additional summary tables and graphs can be found in Appendix B.

\section{Odds Ratio Results}

For eastern Oregon the odds ratio value results suggest that FCGs NEPA documents are less likely to be appealed compared to non-FCG NEPA documents but was not significant at alpha = 0.10 (Table 4, Figure 6). Looking at each National Forest individually, the same result as eastern Oregon is found for the Deschutes National Forest, Ochoco National Forest, and the 
Wallowa-Whitman National Forest (Table 4, Figure 6). The Fremont-Winema National Forest and Malheur National Forest odds ratio value results suggest that FCG NEPA documents are more likely to be appealed but are not significant at alpha $=0.10$ (Table 4, Figure 6). An odds ratio value was not calculated for the Umatilla National Forest since it did not have a two-bycontingency table. The R package vcd does allow for calculation of an odds ratio value by substituting 0.5 into any cells with a zero in a two-by-two contingency table; however this was not done in order to prevent presenting invalid results.

For the years 2006, 2007, and 2012, the odds ratio values suggest that FCG NEPA documents are less likely to be appealed but are not significant at alpha $=0.10$ (Table 6, Figure 5). The year 2008 was found to have an equal likelihood between non-FCG NEPA documents and FCG NEPA

documents. The point value results for 2009 and 2010 suggest non-Forest Collaborative Group NEPA documents are less likely to be appealed (Table 6, Figure 5). Since the year 2011 did not have any FCG NEPA documents a valid odds ratio value could not be returned. The R package vcd allows calculation of an odds ratio value by substituting 0.5 into any cells with a zero in a two-by-two contingency table. This calculation was done using the substituted values (Figure 5), but it should be noted that this is not a valid result and should not be used to draw conclusions about the 2011 year.

\section{Discussion and Conclusion}

My results suggest that FCG NEPA documents for timber sale and fuel treatment projects are less likely to be appealed for eastern Oregon compared to non-FCG NEPA documents when 
looking just at the odds ratio values. When looked at individually, the National Forests differ in which odds ratio values suggest whether FCG NEPA documents are less likely to be appealed in comparison to non-FCG NEPA documents. Although these results are not significant $(\alpha=0.10)$, there is much more context that needs to be examined in order to help place the results of this study.

While these FCGs make their best effort to get all the relevant local stakeholders to the table, the NEPA process still allows for external parties to interject in projects developed with local collaboration. These external parties can file an appeal or objection that has the potential to stall a project that had strong local collaboration and agreement. This could lead to a delay or even withdrawal of proposed projects (Keele et al 2006, Broussard \& Whitaker 2009, Miner et al. 2010). Such a delay would be costly both in economic and ecological terms. Rural communities that may benefit from a proposed project (providing jobs) would have to wait and see if the proposed project will continue or if the project will be withdrawn. There could also be ecological consequences from a delayed or cancelled project. Stands will remain overstocked and pose potential wildfire risks (Arno \& Fiedler 2005). My research found that there were 47 different parties that appealed or objected a project during my study timeframe. Of these 47 parties, six were from outside the State of Oregon. To see if these out of state parties were affecting my results, I removed the projects that only had out of state appellants/objectors and reran odds ratio analysis. Three projects needed to be removed; one project on the Fremont-Winema National Forest, the Malheur National Forest, and the Ochoco National Forest. I also reran eastern Oregon with the three projects removed. The results of 
this rerun analysis did increase the odds ratio values and $90 \%$ confidence intervals but does not change the significance $(\alpha=0.10)$ for any of the National Forests or eastern Oregon. There have been times where collaboration has helped prevent appeals from national chapters of organizations. On the Deschutes National Forest a local chapter of a national organization was involved with collaboration for a proposed project. This local chapter in turn went to the state chapter and requested that the state chapter not appeal the project (Phil Chang, personal communication 2014). This suggests that if the right mix stakeholders are involved in the planning of projects there could be an overall reduction in project appeals and objections.

Because timber sale and fuel treatment projects are often very controversial (Teich et al. 2004, Keele et al. 2006, Laband et al. 2006, Broussard \& Whitake 2009), they are among the most often appealed and litigated project types undertaken by the USFS (Teich et al. 2004, Keele et al. 2006, Broussard \& Whitake 2009). The results of my analysis support the existing literature by demonstrating that it did not matter if a FCG was involved in the NEPA planning of a project when looking at the likelihood of that document being appealed or objected. However, the Wallowa-Whitman National Forest was close $(p$-value $=0.12)$ to exhibiting a significant likelihood that projects that went through a FCG were less likely to be appealed or objected compared to projects developed without FCG engagement. It remains to be seen whether the other National Forests will experience a similar trend as the FCGs located on those National Forests get more experience working together and with the USFS. 
There are also issues with time and capacity for these FCGs to actually engage in the NEPA process. Looking through the data collected for this project and personal communication with various FCG contacts, a time lag exists between FCG formation and the first NEPA project document that is put to the collaborative group. The time gap appears to be approximately two years. So for instance, the Blue Mountains Forest Partners on the Malheur National Forest formed in 2006 but their first NEPA project document did not appear until 2008. The same trend applies for the Harney County Restoration Collaborative, also located on the Malheur National Forest. The group formed in 2008 and finished their first NEPA project document in 2010. I believe the reason this two year time lag occurs due to the FCG setting a mission statement, establishing relationships among stakeholder members and learning the NEPA process requirements. It takes time for the stakeholders to develop a mission statement for their collaborative group that all the stakeholders can agree on. Trust between the stakeholders also needs time to develop; some groups may be made up of stakeholders that traditionally did not get along. Additionally, the capacity of these FCGs does not appear to be high in that these groups can engage in about one NEPA project per year. Some of the older and more established FCGs (Wallowa Country Natural Resource Advisory Committee, Lakeview Stewardship Group, Central Oregon Partnership for Wildfire Risk Reduction) can do two or three projects a year but not every year. In 2011 there were no NEPA documents for which a FCG participated. This absence of FCG NEPA documents in 2011 may be due to the limited capacity of a FCG but it could also have been caused from what occurred during 2009 and 2010. From 2006 to 2008 only three of 16 FCG NEPA documents were appealed or objected; however in 2009 and 2010 five of the 11 FCG NEPA documents were appealed or objected. It wasn't 
until 2012 that FCG NEPA documents appeared again. The gap in 2011 could be explained by the sharp increase in appeals and objections during 2009 and 2010. My research did not look into what the exact cause of the increase in appeals and objections but it could be those were projects the USFS knew would be controversial and the USFS went to the FCGs in an attempt to prevent appeals and objections.

It should be noted that my project used FCGs that are recognized by the State of Oregon (Oregon Solutions 2013). Governor Kitzhaber and his administration have been very invested and supportive of these groups and this has created a unique situation in Oregon. These FCGs were not the only groups of stakeholders that collaborate with the USFS on timber sale and fuel treatment projects from 2006 to 2012 . The USFS has engaged ad hoc groups of stakeholders for various projects. These projects were not included as FCG projects during analysis. Had these projects been treated the same as FCG projects, there would be a greater proportion of collaborative projects. I was able to get USFS input for the Malheur National Forest on what the USFS considered a collaborative project. This list of what the USFS considered collaborative was much larger than the FCGs responses. The FCGs noted they worked on five projects ( 3 for the Blue Mountains Forest Partners and 2 for the Harney Country Restoration Collaborative) while the USFS indicated 17 projects that were collaborative. The increase in collaborative NEPA projects lead to an increase in the number of collaborative projects that were appealed or objected. Running odds ratio analysis with this new list, it was found that the USFS list showed that non-FCG NEPA documents were less likely to be appealed compared to FCG NEPA documents and was significant $(\alpha=0.10)$. The results I found using just the FCG responses 
were not significant $(\alpha=0.10)$ but the odds ratio value did suggest that non-FCG NEPA documents were less likely to be appealed compared to FCG NEPA documents. This suggests that increasing what is considered a collaborative project does not automatically mean the likelihood of an appeal or objection decrease. As stated above, the USFS may have been trying to prevent appeals and objections by collaborating with certain groups on projects the USFS perceived as being controversial.

The question that my project raises is if these FCGs are not having a noticeable effect on appeals and objections, then why continue to engage in collaboration with them or collaboration at all? There are many other benefits to collaboration besides reduction of appeals and objections that have been well documented in the literature (Selin et al. 1997, Carr et al. 1998, Waage 2003). These benefits include, but are not limited to, building trust and relationships between stakeholders and Federal agencies (Selin et al. 1997, Carr et al. 1998, Waage 2003), building trust and relationships among the stakeholders themselves (Selin et al. 1997, Carr et al. 1998, Waage 2003), getting the correct group of stakeholders to the table (Hibbard \& Madsen 2003), and better planning documents for the USFS (Selin et al. 1997, Carr et al. 1998). These benefits should not be overlooked. Additionally, because Oregon is very interested in these FCGs, this interest by Oregon could be an avenue for increasing the capacity of these groups to be able to engage in more than one project per year. The relationships forged between the USFS and the stakeholders may lead to better projects in the future or the ability for projects in other natural resource management to be smoother. Waage (2003) looked at the collaborate effort that went into salmon recovery planning in Wallowa county. 
She found that in that particular instance the collaborative effort had not shaped resource management decisions however the relationships forged during the process could lead to a change in social and political ideologies and natural resource management in the county. The data for my research suggests that this could be occurring presently in Wallowa County. The Wallowa County Natural Resource Advisory Committee had eleven projects during the timeframe for this study and only one was appealed. The collaborative process being undertaken by the other FCGs on the other National Forests may lead to a change in natural resource management outside of just forestry.

\section{Management Implications}

I believe that my research can help inform the FCGs, the USFS, and the State of Oregon. Starting with the established FCGs I would suggest that these groups continue to be actively engaged with the USFS on projects, especially more controversial projects willing to push the envelope of what has been historically acceptable. The FCGs on the Malheur have been more willing to be aggressive and push the envelope (removal of trees over 21 " DBH) on projects they have been involved with (Nils Christoffersen, personal communication 2014). This type of aggressiveness may lead to conflicts between stakeholders within the FCG itself; it will most likely attract the attention of outside stakeholders not willing to see such aggressiveness. However, if the goal of these FCGs is to restore the forests to better ecological conditions that are more resilient to changes and outbreaks, then projects that work toward that goal need to be pushed. I would also suggest the FCGs make sure they are including all the relevant stakeholders not only to their immediate region, but those that may be watching the region for 
afar. I believe the FCGs should make an attempt at including as many stakeholders as possible within a reasonable distance from the National Forest of interest. A few of the FCGs, such as the Central Oregon Partnership for Wildfire Risk Reduction and Deschutes Collaborative Forest Project, noted when they did post implementation monitoring of projects. This practice of multiparty monitoring should continue to be pursued and encouraged to those FCGs not currently engaging in post implementation monitoring. This would allow the FCGs to see if the projects they worked on with the USFS are actually working. Post implementation monitoring could also be used to help further develop relationships between stakeholders and between stakeholders and the USFS. Monitoring could also provide valuable data to both the FCGs and the USFS that could be incorporated into future projects.

For new and younger FCGs I suggest starting out with projects that are not very controversial. While it may be tempting to pursue a large controversial project, it may result in causing conflict within the FCG that could render the FCG ineffective or lose stakeholders from the group. Smaller projects can help build the relationships needed to work toward larger projects and can be used as stepping stones to get to those larger projects. Building trust and relationships is important to getting projects developed and implemented. Nils Christoffersen (personal communication 2014) mentioned to me that he believes the long history of collaboration in Wallowa County benefitted the projects conducted during my research's timeframe. In addition to taking the time to develop relationships, I believe FCGs should make sure they are including all the relevant stakeholders, especially environmental stakeholders. 
Hibbard \& Madsen (2003) found that involving environmental stakeholders and making sure they have a voice in a FCG is important for the group to succeed.

For the USFS, I suggest they continue to engage and work with FCGs in Oregon. The USFS should consider the age and relationship they have with the FCG they are working with and bring projects to the group based upon those characteristics. As mentioned above, newer FCGs and the USFS should work on getting smaller projects implemented before moving on to larger projects. For more established FCGs with good relationships with the USFS, I suggest the USFS be willing to bring more controversial projects to the group. While this in no way guarantees there will not be appeals or objections, it does allow the USFS to get a feel of what will and what will not be accepted by the stakeholders of the FCG. As mentioned above, I suggest that the USFS allow the FCG to engage in some meaningful form of post implementation monitoring. Not only will this help build the relationship with the FCG, but it will provide the USFS with valuable information that can be used to inform future projects. Much like how watershed council in Oregon do monitoring for the Oregon Plan for Salmon and Watersheds, the FCGs could do monitoring for the USFS.

To the State of Oregon I suggest continued interest in the FCGs as well as providing financial backing to the FCGs to help them expand their capacity to engage in projects. As far as providing continued interest, I would suggest that the State continue to actively show support for the FCGs and the work they do through the Federal Forestlands Advisory Committee (FFAC). Because the FFAC helped to develop the statewide inventory (Oregon Solutions 2013), the FFAC 
is familiar with the workings of the FCGs. The FFAC could provide suggestions on how groups could better organize themselves or include stakeholders whose voice may be currently left out. For financial support, the Oregon Plan for Salmon and Watersheds could be modified for forest landscapes. The FCGs would will the role that watershed councils currently hold and would participate in development of projects and post implementation monitoring. The FCGs could submit grant proposal to a state agency, perhaps the Oregon Board of Forestry or the FFAC, and grants could be given out based on those proposals. Since there are only 23 FCGs as of 2013 (Oregon Solutions 2013) there could be a substantial amount of money available in grants. Like the Oregon Plan for Salmon and Watersheds, I suggest the grants to be used to expand the capacity of the FCGs. Because capacity appears to be a limiting factor for the FCGs, expansion of the FCGs capacity could lead to more FCG projects. These grants could allow the FCGs to hire full time employees who could engage with the USFS more often than the FCG currently does. Most of the members of the FCGs are volunteering their time to be involved with the group and having the ability to hire someone who could be engaged with the FCG full time could lead to greater project engagement. More projects would provide more data for future research relating to FCGs and their effectiveness.

\section{Future Research}

My research should be viewed as a start and further research is merited. There are five possible future directions research could go in relation to the FCGs and collaboration in general. First, as mentioned above these FCGs are capacity limited. Due to this limitation and the timeframe of my research there is a very small sample size of FCG NEPA documents. To 
overcome the issue of small sample size the timeframe could have been extended back to the early 2000's or earlier. My research could also be revisited in five to ten years' time to see if over a longer timeframe FCGs are being effective at reducing the likelihood of project objections (as of 2013 the post-decisional appeals process has been replaced with the predecisional objection process). With an increased sample size over a longer timeframe the analysis could be done as a binned year analysis instead of a year by year analysis for eastern Oregon. A year by year analysis may never show significant results due to the low number of FCG NEPA documents per year. A five year bin would potentially include more FCG projects and could produce results that better demonstrate the effect FCGs are having.

Second, it would also be interesting to look at how engagement with FCGs shifts the NEPA timeline to a Record of Decision for timber sale and fuel treatment projects. Does engagement with a FCG quicker the time to a Record of Decision? Or does the time required to complete the NEPA process and get to a Record of Decision stay the same regardless of FCG engagement? In terms of litigation it would be interested to see if FCG NEPA documents are taken all the way to litigation as opposed to non-FCG NEPA documents. Additionally, one could look to see if the USFS wins more litigated cases on collaborative projects. This type of research would begin to get at if collaboration and these FCGs are saving the USFS in litigation cost for projects that are often controversial already.

A third future research suggestion would look at the stakeholders that make up FCGs. Looking first at the individual stakeholders, it would be interested to know if their 
appeal/objection/litigation behavior changes over time as they get involved with a FCG. Does a group that historically appeals and litigates a lot begin to reduce the number of appeals as it gets more involved with a FCG or does it stay the same even after joining a FCG? Additionally, it would also be thought provoking to see if there is a difference in stakeholders appealing behavior in areas they collaborate against areas where the stakeholder is not involved in a FCG or collaborative planning process with the USFS.

Fourth, research could be conducted to look at the affect the FCGs are having on the behavior of the USFS at the individual National Forest level. Research could compare pre and post FCG establishment to see if there is a difference in project types being undertaken, are projects getting larger or staying the same, are projects starting to push the boundaries of what was historically the norm or are they saying with the range of historical project limits, and how the appeals and objections rates have changes pre and post FCG establishment. This type of research would help inform how the FCGs are affecting the National Forests as a whole instead of just looking at two project types (timber sales and fuel treatment projects). It would also be interesting to see if the USFS is becoming more willing to have these FCGs conduct post implementation monitoring to see how well the projects are meeting their purpose and need statements.

Finally, it would be fascinating to see if the anecdotal evidence noted in Selin et al. (1997) and Carr et al. (1998) is reflected in these FCGs and USFS employees. Selin et al. (1997) and Carr et al. (1998) found that USFS employee believe collaboration can reduce appeals and litigation in 
addition to identifying benefit and barriers to collaboration. It seems that an update on what those two studies found would be incredibly beneficial to both the FCGs and USFS. The research could focus on what USFS employees and FCG participants believe is working, what are continued barriers to engagement with each other, and what other benefits or costs (economic or otherwise) collaboration with FCGs have on the USFS. The results of this study could be used to focus in on areas that are working and areas that are still providing contentious or difficult to overcome.

\section{Conclusion}

Forest management produces many different issues that have no right or wrong answer, a classic 'wicked problem' (Rittel \& Webber 1973, Allen \& Gould 1986). Collaboration is not a perfect solution to all wicked problems however it can help reach resolutions to wicked

problems. With the State's backing, FCGs will continue to be encouraged to work with the USFS on local projects that will benefit the stakeholders and the agency. As groups engage in more projects and continue to build relationships it may finally be possible to see empirical evidence of these groups working. The social and political environment should not be ignored when doing future analysis of these FCGs and the effectiveness they are having on timber sale and fuel treatment projects. 


\section{Figures}

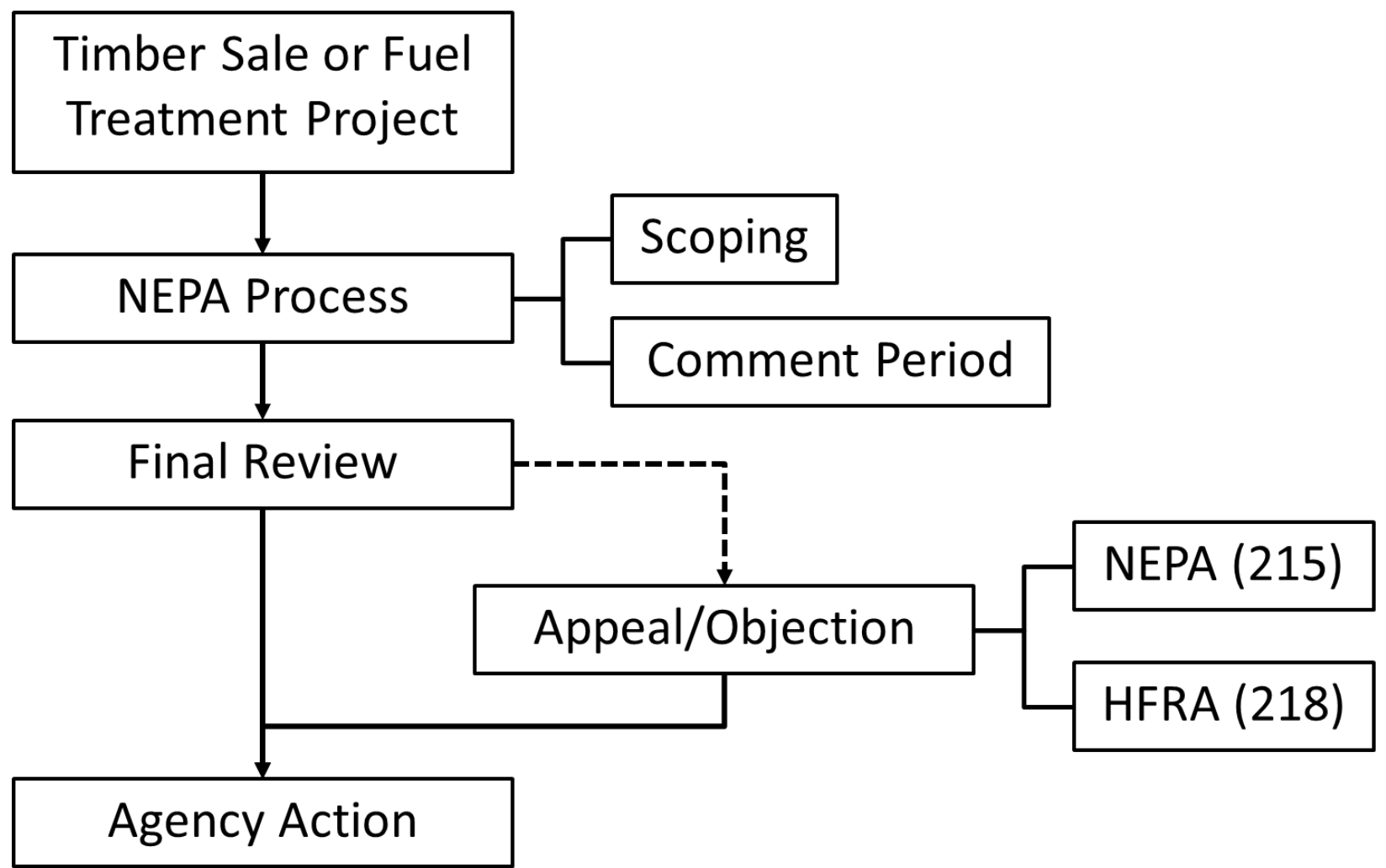

Figure 1 - Federal project process flow chart for proposed timber sale and fuel treatment projects. The National Environmental Policy Act (NEPA) process is the same for timber sale and fuel treatment project documents. After Final Review, the United States Forest Service makes a decision on if to move forward to Agency Action. Should a NEPA document get appealed or objected, the Federal project process follows the dashed line after Final Review. Project NEPA documents coded with NEPA regulation 215 are subject to post-decisional appeals. Project NEPA documents that were developed under the Healthy Forest Restoration Act (HFRA) are coded with the NEPA regulation 218 and subject to pre-decisional objections. All appeals and objections must be resolved before the project can move to Agency Action. 


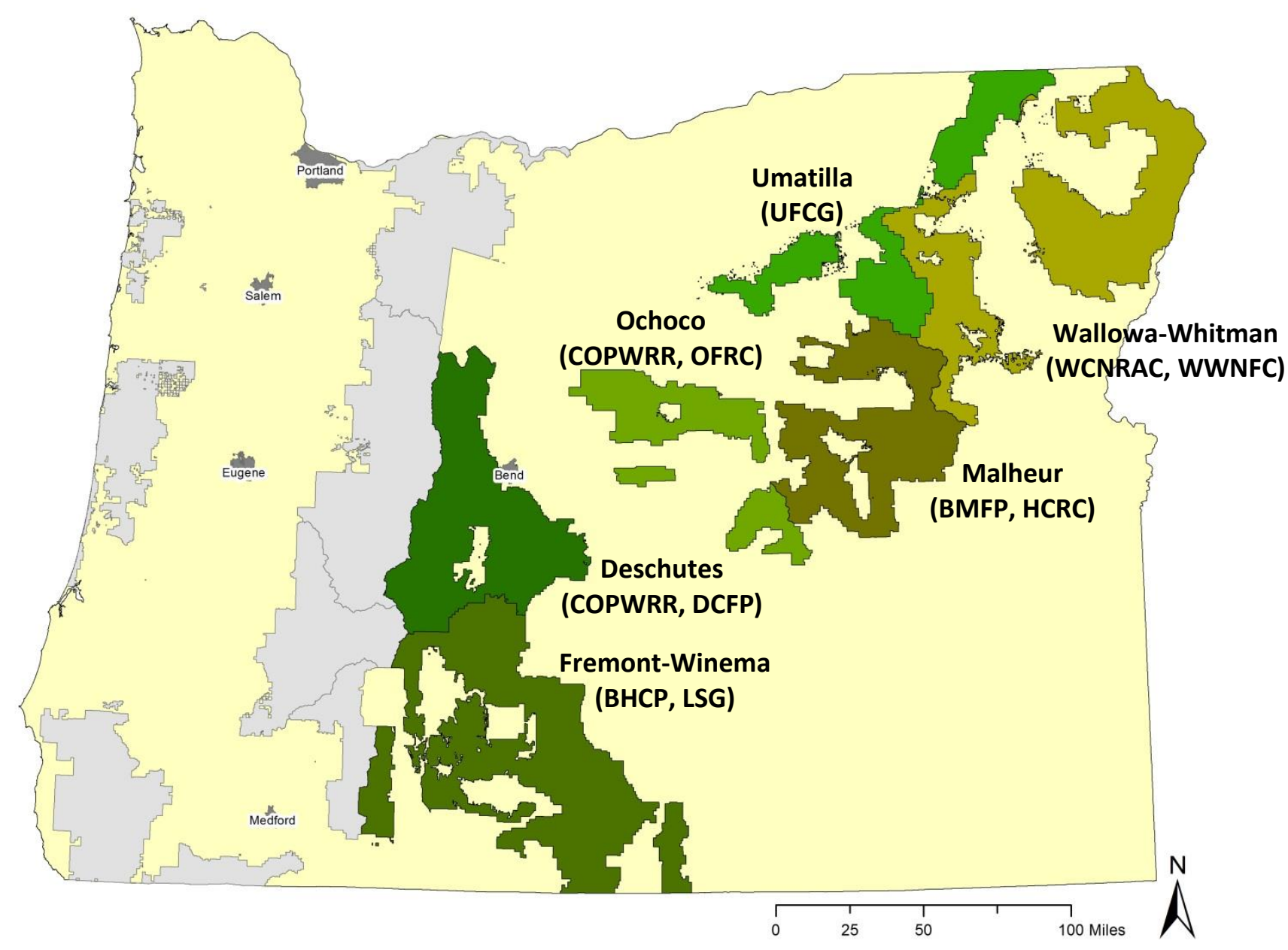

Figure 2 - National Forest and Forest Collaborative Groups location in Oregon. The National Forests in green are those which were included in the analysis. Initials in parenthesis under National Forest name indicate those Forest Collaborative Groups that are interested in that particular National Forest. See Table 1 for information about each Forest Collaborative Group. 


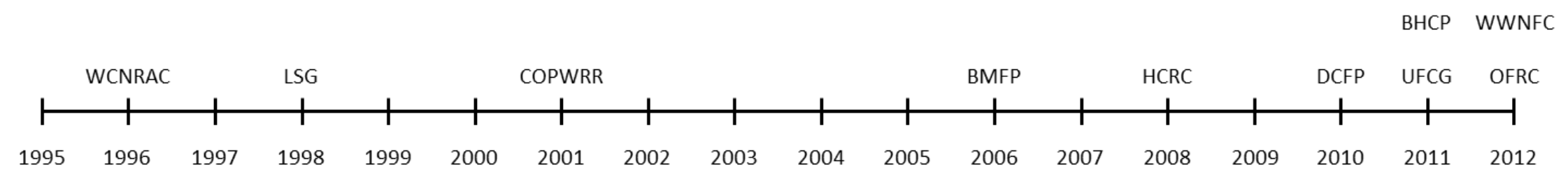

Figure 3 - Eastern Oregon Forest Collaborative Group establishment from 1995 to 2012. BHCP: Black Hills Collaborative Project, BMFP: Blue Mountains Forest Partners, COPWRR: Central Oregon Partnership for Wildfire Risk Reduction, DCFP: Deschutes Collaborative Forest Project, HCRC: Harney County Restoration Collaborative, LSG: Lakeview Stewardship Group, OFRC: Ochoco Forest Restoration Collaborative, UFCG: Umatilla Forest Collaborative Group, WCNRAC: Wallowa County Natural Resource Advisory Committee, WWNFC: Wallowa-Whitman National Forest Collaborative. 


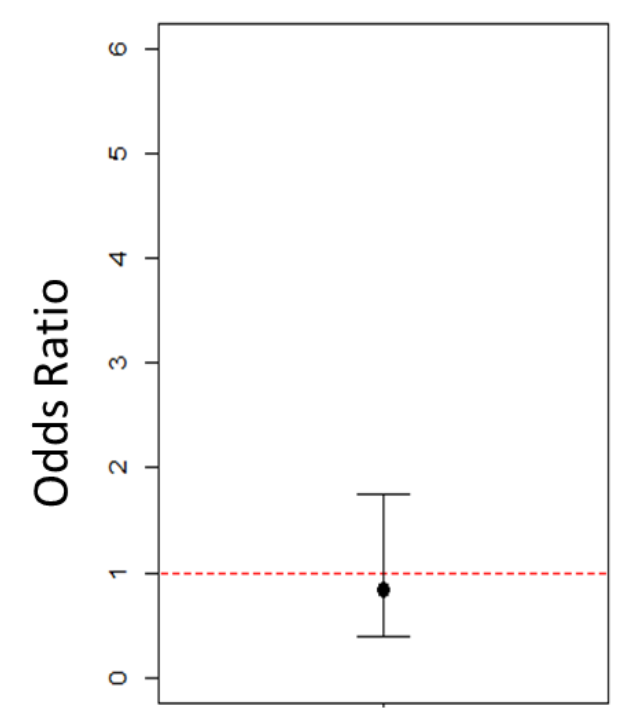

Eastern Oregon
Deschutes

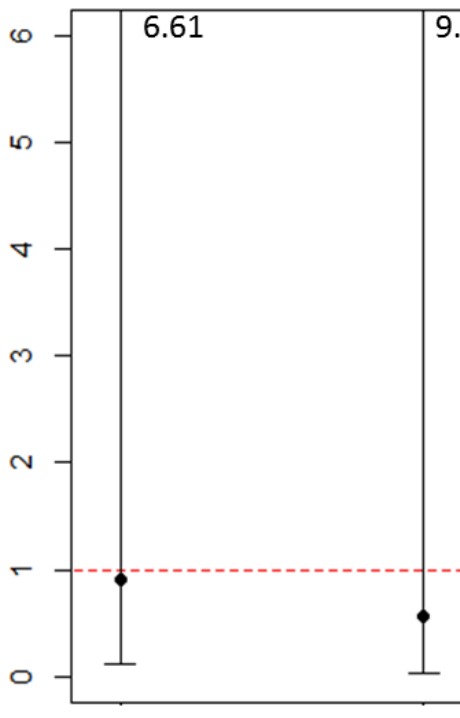

Ochoco
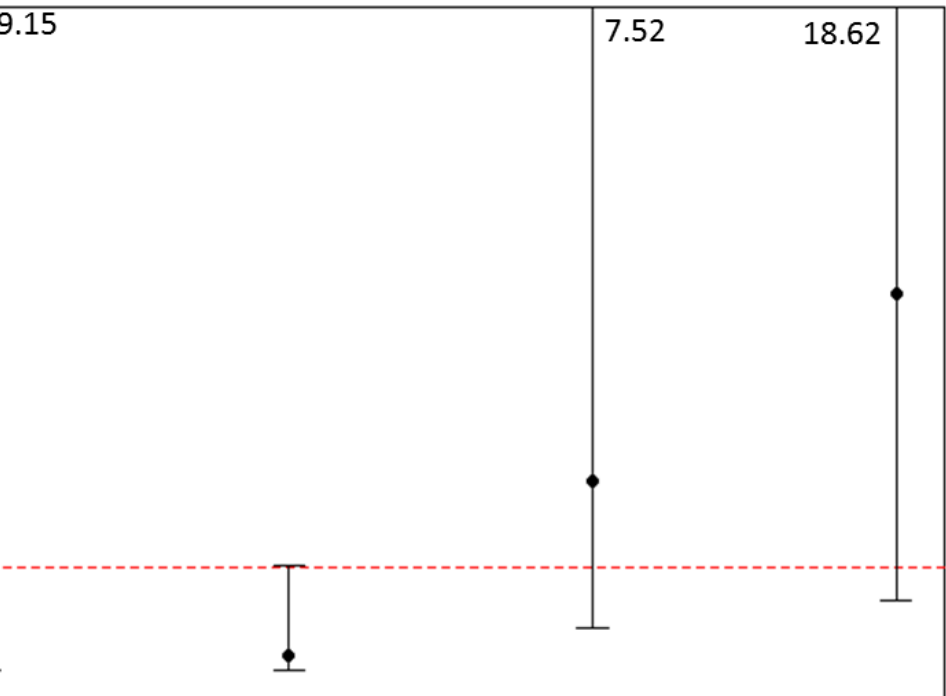

$n=165$

$n=41$

$n=23$

\section{Whitman}

Fremont-

Malheur

Winema

$n=32$

$\mathrm{n}=37$

$\mathrm{n}=32$

Figure 4 -Odds ratio values and $90 \%$ confidence intervals for eastern Oregon and individual National Forest. Eastern Oregon is the amalgamation of all individual National Forests except the Umatilla National Forest. The Umatilla National Forest is not included in the analysis. The 1 line is indicated by red dashed line. If $90 \%$ confidence intervals encompasses the 1 line, there is an equal likelihood of an appeal being assocaited with a non-Forest Collaborative Group NEPA documents and a Forest Collaborative Group NEPA documents. Odds ratio values: Eastern Oregon 0.837, Deschutes 0.900, Ochoco 0.569, Wallowa-Whitman 0.160, Fremont-

Winema 1.800, Malheur 3.563. 


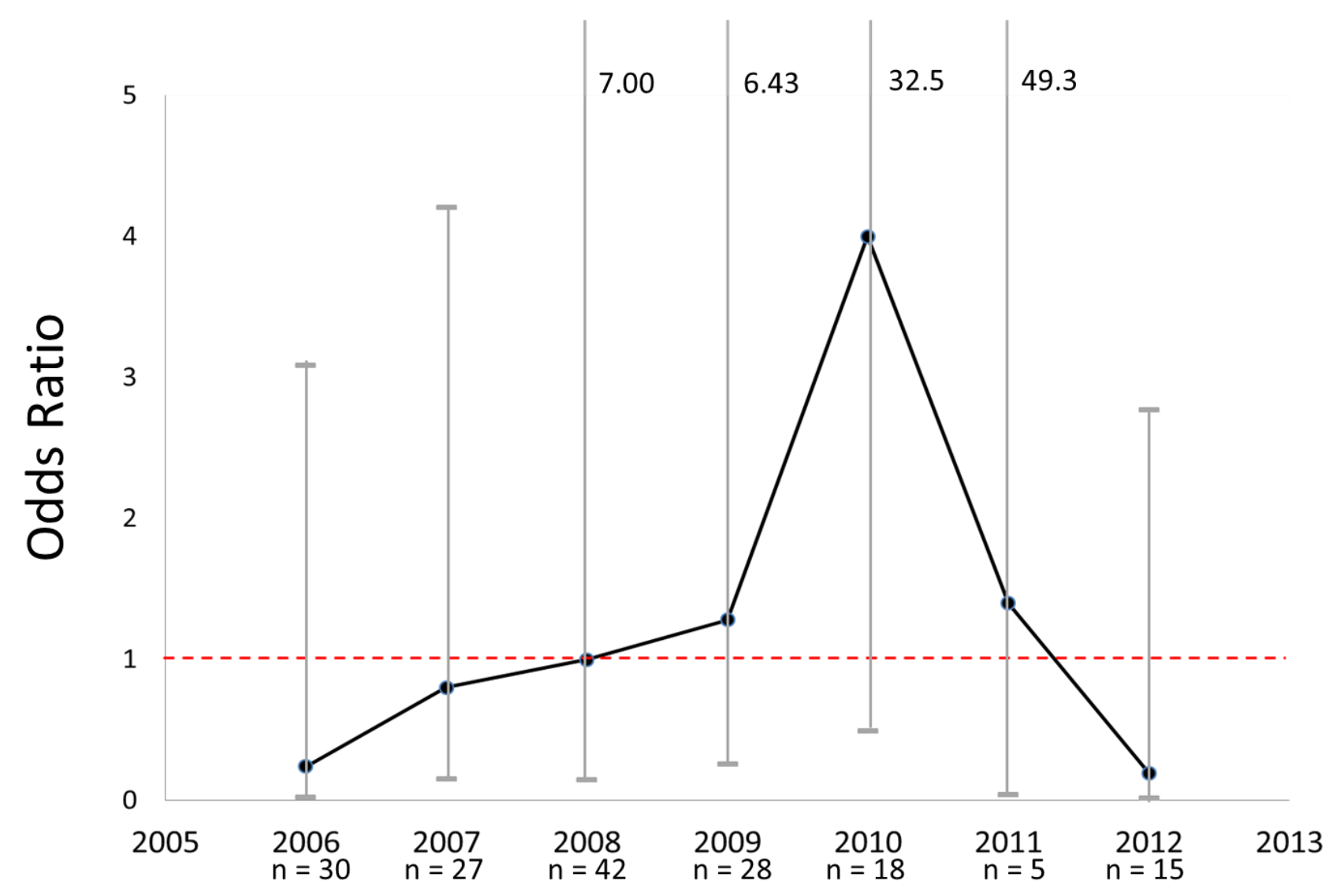

Figure 5 - Odds ratio values and $90 \%$ confidence intervals for eastern Oregon by year (the Umatilla National Forest records are not included in these results). The 1 line is indicated by red dashed line. If $90 \%$ confidence interval encompasses the 1 line, there is an equal likelihood of an appeal for non-FCG NEPA documents and FCGs NEPA documents. The year 2011 should be not used to draw conclusions about that year as it is an invalid result. There were no Forest Collaborative Group NEPA documents in 2011 and thus there were zeroes in the two-by-two contingency tables. The R package vod subsititued in values of 0.5 for these zeros and allowed for calculation of an odds ratio value. 
Tables

Table 1 - Name, abbreviation, year established, and geographic extent of the Forest Collaborative Groups in eastern Oregon. Some of the Forest Collaborative Groups only interested in certain USFS Ranger Districts or Oregon counties; others interested with entire National Forests.

\begin{tabular}{|l|c|c|l|}
\hline \multicolumn{1}{|c|}{ Name } & Abbreviation & $\begin{array}{c}\text { Year } \\
\text { Established }\end{array}$ & \multicolumn{1}{|c|}{ National Forest and Geographic Extent } \\
\hline Black Hills Collaborative Project & BCHP & 2011 & Fremont-Winema; Bly Ranger District \\
\hline Blue Mountains Forest Partners & BMFP & 2006 & Malheur; Grant and Harney counties \\
\hline Central Oregon Partnership for Wildfire Risk Reduction & COPWRR & 2001 & Deschutes, Ochoco \\
\hline Deschutes Collaborative Forest Project & DCFP & 2010 & Deschutes; DCFP landscape \\
\hline Harney County Restoration Collaborative & HCRC & 2008 & Malheur; Harney county \\
\hline Lakeview Stewardship Group & LSG & 1998 & Fremont-Winema; Lakeview Stewardship Unit \\
\hline Ochoco Forest Restoration Collaborative & OFRC & 2012 & Ochoco \\
\hline Umatilla Forest Collaborative Group & UFCG & 2011 & Umatilla \\
\hline $\begin{array}{l}\text { Wallowa County Natural Resource Advisory } \\
\text { Committee }\end{array}$ & WCNRAC & 1996 & Wallwa-Whitman; Wallowa county \\
\hline Wallowa-Whitman National Forest Collaborative & WWNFC & 2012 & Wallowa-Whitman \\
\hline
\end{tabular}


Table 2 -NEPA documents summary information for eastern Oregon and for each National Forest from 2006 to 2012 . Total Number of NEPA Documents gives the total number of NEPA documents for all project types; this includes timber sale and fuel treatment project types. Timber/Fuels NEPA Documents gives the total number of NEPA documents for timber sale and fuel treatment project types. Number Appealed and Objected give the total number of NEPA documents that received an appeal or an objection.

\begin{tabular}{|l|c|c|c|c|}
\hline & $\begin{array}{c}\text { Total Number of NEPA } \\
\text { Documents }\end{array}$ & $\begin{array}{c}\text { Number Appealed and } \\
\text { Objected }\end{array}$ & $\begin{array}{c}\text { Timber/Fuels NEPA } \\
\text { Documents }\end{array}$ & $\begin{array}{c}\text { Number Appealed and } \\
\text { Objected }\end{array}$ \\
\hline Deschutes & 89 & 18 & 41 & 11 \\
\hline Fremont-Winema & 66 & 12 & 32 & 8 \\
\hline Malheur & 56 & 11 & 32 & 11 \\
\hline Ochoco & 39 & 13 & 23 & 8 \\
\hline Umatilla & 64 & 23 & 37 & 18 \\
\hline Wallowa-Whitman & 81 & 21 & 37 & 11 \\
\hline Eastern Oregon & 395 & 98 & 202 & 67 \\
\hline
\end{tabular}


Table 3 - Number of timber sale and fuel treatment project NEPA documents the Forest Collaborative Groups participated in and how many of those documents were appealed or objected to. Answers were collected from contacts for each Forest Collaborative Group and then grouped by National Forest the group is concerned with.

\begin{tabular}{|l|c|c|}
\hline & $\begin{array}{c}\text { Number of NEPA Documents Developed with a } \\
\text { Forest Collaborative Group }\end{array}$ & $\begin{array}{c}\text { Number of Forest Collaborative Group NEPA } \\
\text { Documents That Were Appealed/Objected }\end{array}$ \\
\hline Deschutes & 4 & 1 \\
\hline Fremont-Winema & 9 & 3 \\
\hline Malheur & 5 & 3 \\
\hline Ochoco & 1 & 0 \\
\hline Umatilla & 0 & 0 \\
\hline Wallowa-Whitman & 11 & 1 \\
\hline Eastern Oregon & 30 & 8 \\
\hline
\end{tabular}


Table 4 - Odds ratio and 90\% confidence intervals for eastern Oregon (all National Forests lumped) and individual National Forests.

Confidence intervals that include 1 indicate an equal likelihood of appeal/objection between non-Forest Collaborative Group NEPA documents and Forest Collaborative Group NEPA documents. *The Umatilla National Forest did not have any Forest Collaborative Group NEPA documents so it was not included in the eastern Oregon analysis. Additionally, a valid odds ratio value could not be calculated for the Umatilla National Forest.

\begin{tabular}{|l|c|c|}
\hline & Odds Ratio (OR) & $90 \%$ Confidence Interval \\
\hline Eastern Oregon & 0.837 & $0.396,1.758$ \\
\hline Deschutes National Forest & 0.900 & $0.122,6.614$ \\
\hline Fremont-Winema National Forest & 1.800 & $0.431,7.520$ \\
\hline Malheur National Forest & 3.563 & $0.682,18.621$ \\
\hline Ochoco National Forest & 0.569 & $0.035,9.151$ \\
\hline Umatilla National Forest* & - & - \\
\hline Wallowa-Whitman National Forest & 0.160 & $0.025,1.016$ \\
\hline
\end{tabular}


Table 5 - Summarization per year from 2006 to 2012 of NEPA documents for eastern Oregon. These totals include the Umatilla

National Forest; however the Umatilla National Forest records were removed for analysis. Total Timber/Fuel NEPA Documents is the total number of NEPA documents for timber sale and fuel treatment projects across eastern Oregon. Total Documents

Appealed/Objected is the number of documents that were appealed or objected across eastern Oregon. FCG Timber/Fuel NEPA

Documents is the number of FCG NEPA documents for timber sale and fuel treatment project types across eastern Oregon. FCG

Timber/Fuel Documents Appealed/Objected is the number of FCG NEPA documents that were appealed or objected for timber sale and fuel treatment projects across eastern Oregon.

\begin{tabular}{|c|c|c|c|c|}
\hline Year & $\begin{array}{c}\text { Total Timber/Fuel NEPA } \\
\text { Documents }\end{array}$ & $\begin{array}{c}\text { Total Documents } \\
\text { Appealed/Objected }\end{array}$ & $\begin{array}{c}\text { FCG Timber/Fuel NEPA } \\
\text { Documents }\end{array}$ & $\begin{array}{c}\text { FCG Timber/Fuel Documents } \\
\text { Appealed/Objected }\end{array}$ \\
\hline 2006 & 35 & 11 & 4 & 0 \\
\hline 2007 & 36 & 16 & 5 & 2 \\
\hline 2008 & 51 & 9 & 7 & 1 \\
\hline 2009 & 35 & 10 & 7 & 2 \\
\hline 2010 & 19 & 10 & 4 & 3 \\
\hline 2011 & 7 & 4 & 0 & 0 \\
\hline 2012 & 19 & 7 & 3 & 0 \\
\hline
\end{tabular}


Table 6 - Odds ratio and 90\% confidence intervals for each year from 2006 to 2012 for eastern Oregon. Confidence intervals that include 1 indicate an equal likelihood of appeal/objection between non-Forest Collaborative Group NEPA documents and Forest Collaborative Group NEPA documents. ${ }^{*} 2011$ did not have any Forest Collaborative Group NEPA documents and a valid odds ratio value could not be calculated.

\begin{tabular}{|c|c|c|}
\hline 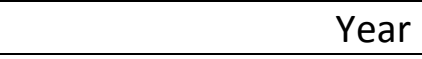 & Odds Ratio (OR) & 90\% Confidence Interval OR \\
\hline 2006 & 0.2418 & $0.0190,3.0816$ \\
\hline 2007 & 0.8 & $0.1523,4.2012$ \\
\hline 2008 & 1 & $0.1428,7.0021$ \\
\hline 2009 & 1.28 & $0.2549,6.4275$ \\
\hline 2010 & 4 & $0.4914,32.5598$ \\
\hline $2011^{*}$ & - & - \\
\hline 2012 & 0.1948 & $0.0137,2.7647$ \\
\hline
\end{tabular}




\section{References}

Allen, G. M., \& Gould, E. M. (1986). Complexity, wickedness, and public forests. Journal of Forestry, 84(4), 20-23.

Arno, S. F., \& Fiedler, C. E. (2005). Mimicking nature's fire: restoring fire-prone forests in the West. Island Press.

Broussard, S. R., \& Whitaker, B. D. (2009). The Magna Charta of environmental legislation: A historical look at 30 years of NEPA-Forest Service litigation. Forest Policy and Economics, 11(2), 134-140.

Carr, D. S., Selin, S. W., \& Schuett, M. A. 1998. Managing public forests: Understanding the role of collaborative planning. Environmental Management, 22(5), 767-776.

Carroll, M. S., Blatner, K. A., Cohn, P. J., \& Morgan, T. (2007). Managing fire danger in the forests of the US inland northwest: A classic wicked problem in public land policy. Journal of Forestry, 105(5), 239-244.

Federal Forest Advisory Committee - Implementation Work Group. (2012). National Forest Health Restoration: An Economic Assessment of Forest Restoration on Oregon's Eastside National Forests. 94 pp. 
Forest Service Objection Responses for R6 - Pacific Northwest Region All Units. http://www.fs.fed.us/objections/objections list.php?r=110600. Accessed 2014.

Germain, R. H., Floyd, D. W., \& Stehman, S. V. (2001). Public perceptions of the USDA Forest Service public participation process. Forest Policy and Economics, 3(3), 113-124.

Gray, B. (1989). Collaborating: Finding common ground for multiparty problems (Vol. 329). San Francisco: Jossey-Bass.

Hibbard, M., \& Madsen, J. (2003). Environmental resistance to place-based collaboration in the US West. Society \& Natural Resources, 16(8), 703-718.

Keele, D. M., Malmsheimer, R. W., Floyd, D. W., \& Perez, J. E. (2006). Forest Service land management litigation 19892002. Journal of Forestry, 104(4), 196-202.

Laband, D. N., Gonzalez-Caban, A., \& Hussain, A. (2006). Factors that influence administrative appeals of proposed USDA Forest Service fuels reduction actions. Forest Science, 52(5), 477488. 
Leach, W. D. (2006). Public involvement in USDA Forest Service policymaking: a literature review. Journal of Forestry, 104(1), 43-49.

Meyer, D., Zeileis, A., Hornik, K., Gerber, F., \& Friendly, M. (2013). Visualizing categorical data R package.

Miner, A., Malmsheimer, R. W., Keele, D. M., \& Mortimer, M. J. (2010). Twenty years of Forest Service National Environmental Policy Act Litigation. Environmental Practice, 12(02), 116-126.

Oregon Solutions. 2013. Oregon Forest Collaboratives: Statewide Inventory 2013. 98 pp. http://orsolutions.org/osproject/federal-forestlands

“Project-Level Predecisional Administrative Review Process; Final Rule," 77 Federal Register 59 (27 March 2013), pp.18481-18504.

R Core Team. (2013). R: A language and environment for statistical computing. R Foundation for Statistical Computing. Vienna, Austria.

Rittel, H. W., \& Webber, M. M. (1973). Dilemmas in a general theory of planning. Policy sciences, 4(2), 155-169. 
Schuett, M. A., Selin, S. W., \& Carr, D. S. (2001). Making it work: Keys to successful collaboration in natural resource management. Environmental Management, 27(4), 587-593.

Selin, S. W., Schuett, M. A., \& Carr, D. S. (1997). Has collaborative planning taken root in the National Forests?. Journal of Forestry, 95(5), 25-28.

Stern, M. J., Predmore, S. A., Mortimer, M. J., \& Seesholtz, D. N. (2010). The meaning of the National Environmental Policy Act within the US Forest Service. Journal of Environmental Management, 91(6), 1371-1379.

Teich, G. M., Vaughn, J., \& Cortner, H. J. (2004). National trends in the use of Forest Service administrative appeals. Journal of Forestry, 102(2), 14-19.

Waage, S. (2003). Collaborative salmon recovery planning: Examining decision making and Implementation in northeastern Oregon. Society \& Natural Resources, 16(4), 295-307. 
Appendix A

Two-by-Two Contingency Tables 
Two-by-Two Contingency Tables for Eastern Oregon and National Forests

Eastern Oregon

\begin{tabular}{|l|c|c|}
\hline & Not Appealed/Objected & Appealed/Objected \\
\hline Non-Forest Collaborative Group Document & 94 & 41 \\
\hline Forest Collaborative Group Document & 22 & 8 \\
\hline
\end{tabular}

*Umatilla National Forest not included for eastern Oregon analysis.

Deschutes National Forest

\begin{tabular}{|l|c|c|}
\hline & Not Appealed/Objected & Appealed/Objected \\
\hline Non-Forest Collaborative Group Document & 27 & 10 \\
\hline Forest Collaborative Group Document & 3 & 1 \\
\hline
\end{tabular}

Fremont-Winema National Forest

\begin{tabular}{|l|c|c|}
\hline & Not Appealed/Objected & Appealed/Objected \\
\hline Non-Forest Collaborative Group Document & 18 & 5 \\
\hline Forest Collaborative Group Document & 6 & 3 \\
\hline
\end{tabular}

Malheur National Forest

\begin{tabular}{|l|c|c|}
\hline & Not Appealed/Objected & Appealed/Objected \\
\hline Non-Forest Collaborative Group Document & 19 & 8 \\
\hline Forest Collaborative Group Document & 2 & 3 \\
\hline
\end{tabular}

Ochoco National Forest

\begin{tabular}{|l|c|c|}
\hline & Not Appealed/Objected & Appealed/Objected \\
\hline Non-Forest Collaborative Group Document & 14 & 8 \\
\hline Forest Collaborative Group Document & 1 & 0 \\
\hline
\end{tabular}

Umatilla National Forest

\begin{tabular}{|l|c|c|}
\hline & Not Appealed/Objected & Appealed/Objected \\
\hline Non-Forest Collaborative Group Document & 19 & 18 \\
\hline Forest Collaborative Group Document & 0 & 0 \\
\hline
\end{tabular}

Wallowa-National Forest

\begin{tabular}{|l|c|c|}
\hline & Not Appealed/Objected & Appealed/Objected \\
\hline Non-Forest Collaborative Group Document & 16 & 16 \\
\hline Forest Collaborative Group Document & 16 & 1 \\
\hline
\end{tabular}


Two-by-Two Contingency Tables for Eastern Oregon from 2006 to 2012

Eastern Oregon 2006

\begin{tabular}{|l|c|c|}
\hline & Not Appealed/Objected & Appealed/Objected \\
\hline Non-Forest Collaborative Group Document & 18 & 8 \\
\hline Forest Collaborative Group Document & 4 & 0 \\
\hline
\end{tabular}

Eastern Oregon 2007

\begin{tabular}{|l|c|c|}
\hline & Not Appealed/Objected & Appealed/Objected \\
\hline Non-Forest Collaborative Group Document & 12 & 10 \\
\hline Forest Collaborative Group Document & 3 & 2 \\
\hline
\end{tabular}

Eastern Oregon 2008

\begin{tabular}{|l|c|c|}
\hline & Not Appealed/Objected & Appealed/Objected \\
\hline Non-Forest Collaborative Group Document & 30 & 5 \\
\hline Forest Collaborative Group Document & 6 & 1 \\
\hline
\end{tabular}

Eastern Oregon 2009

\begin{tabular}{|l|c|c|}
\hline & Not Appealed/Objected & Appealed/Objected \\
\hline Non-Forest Collaborative Group Document & 16 & 5 \\
\hline Forest Collaborative Group Document & 5 & 2 \\
\hline
\end{tabular}

Eastern Oregon 2010

\begin{tabular}{|l|c|c|}
\hline & Not Appealed/Objected & Appealed/Objected \\
\hline Non-Forest Collaborative Group Document & 8 & 6 \\
\hline Forest Collaborative Group Document & 1 & 3 \\
\hline
\end{tabular}

Eastern Oregon 2011

\begin{tabular}{|l|c|c|}
\hline & Not Appealed/Objected & Appealed/Objected \\
\hline Non-Forest Collaborative Group Document & 0 & 1 \\
\hline Forest Collaborative Group Document & 3 & 2 \\
\hline
\end{tabular}

Eastern Oregon 2012

\begin{tabular}{|l|c|c|}
\hline & Not Appealed/Objected & Appealed/Objected \\
\hline Non-Forest Collaborative Group Document & 7 & 5 \\
\hline Forest Collaborative Group Document & 3 & 0 \\
\hline
\end{tabular}


Appendix B

Summary Tables and Graphs 
Number of NEPA documents for all project types per National Forest per year from 2006 to 2012.

\begin{tabular}{|c|c|c|c|c|c|c|}
\hline Year & Deschutes & Fremont-Winema & Malheur & Ochoco & Umatilla & Wallowa-Whitman \\
\hline 2006 & 9 & 18 & 11 & 5 & 13 & 10 \\
\hline 2007 & 9 & 17 & 12 & 8 & 11 & 10 \\
\hline 2008 & 21 & 5 & 14 & 7 & 15 & 8 \\
\hline 2009 & 11 & 10 & 7 & 3 & 11 & 17 \\
\hline 2010 & 12 & 6 & 5 & 6 & 4 & 3 \\
\hline 2011 & 5 & 4 & 1 & 2 & 7 & 6 \\
\hline 2012 & 22 & 6 & 6 & 4 & & 19 \\
\hline
\end{tabular}

Number of appeals and objections for NEPA documents for all project types per National Forest per year from 2006 to 2012.

\begin{tabular}{|c|c|c|c|c|c|c|}
\hline Year & Deschutes & Fremont-Winema & Malheur & Ochoco & Umatilla & Wallowa-Whitman \\
\hline 2006 & 0 & 1 & 2 & 1 & 4 & 3 \\
\hline 2007 & 4 & 3 & 1 & 3 & 4 & 4 \\
\hline 2008 & 1 & 1 & 3 & 4 & 0 & 3 \\
\hline 2009 & 5 & 1 & 3 & 2 & 3 & 3 \\
\hline 2010 & 2 & 4 & 0 & 1 & 2 & 4 \\
\hline 2011 & 3 & 2 & 1 & 2 & 2 & \\
\hline 2012 & 3 & 0 & & & & 4 \\
\hline
\end{tabular}


Number of NEPA documents for timber sale and fuel treatment project types per National Forest per year from 2006 to 2012.

\begin{tabular}{|c|c|c|c|c|c|c|}
\hline Year & Deschutes & Fremont-Winema & Malheur & Ochoco & Umatilla & Wallowa-Whitman \\
\hline 2006 & 5 & 9 & 4 & 4 & 5 & 8 \\
\hline 2007 & 5 & 6 & 6 & 5 & 9 & 5 \\
\hline 2008 & 13 & 5 & 10 & 7 & 7 & 7 \\
\hline 2009 & 9 & 6 & 4 & 3 & 1 & \\
\hline 2010 & 6 & 2 & 0 & 1 & 2 & 3 \\
\hline 2011 & 1 & 2 & 4 & 2 & 4 & 1 \\
\hline 2012 & 2 & 2 & & & 5 \\
\hline
\end{tabular}

Number of appeals and objections for NEPA documents for timber sale and fuel treatment project types per National Forest per year from 2006 to 2012.

\begin{tabular}{|c|c|c|c|c|c|c|}
\hline Year & Deschutes & Fremont-Winema & Malheur & Ochoco & Umatilla & Wallowa-Whitman \\
\hline 2006 & 1 & 0 & 2 & 1 & 3 & 4 \\
\hline 2007 & 3 & 3 & 2 & 2 & 4 & 2 \\
\hline 2008 & 1 & 1 & 2 & 1 & 0 & 3 \\
\hline 2009 & 4 & 1 & 1 & 2 & 1 & 1 \\
\hline 2010 & 1 & 2 & 3 & 1 & 2 & 1 \\
\hline 2011 & 0 & 1 & 0 & 1 & 2 & 0 \\
\hline 2012 & 1 & 0 & 1 & & 2 \\
\hline
\end{tabular}


Number of timber sale and fuel treatment NEPA documents that had Forest Collaborative Group per National Forest. Collaborative NEPA Documents is the number of NEPA documents Forest Collaborative groups participated in. Not Appealed/Objected and Appealed/Objected are the number of collaborative NEPA documents that were either not appealed/objected or were appealed/objected.

\begin{tabular}{|l|l|l|l|}
\hline National Forest & Collaborative NEPA Documents & Not Appealed/Objected & Appealed/Objected \\
\hline Deschutes & 4 & 3 & 1 \\
\hline Fremont-Winema & 9 & 6 & 3 \\
\hline Malheur & 5 & 2 & 3 \\
\hline Ochoco & 1 & 1 & 0 \\
\hline Umatilla & 0 & 0 & 0 \\
\hline Wallowa-Whitman & 11 & 10 & 1 \\
\hline
\end{tabular}

Number of timber sale and fuel treatment project type NEPA documents that had Forest Collaborative Group input per National Forest per year from 2006 to 2012.

\begin{tabular}{|c|c|c|c|c|c|c|}
\hline Year & Deschutes & Fremont-Winema & Malheur & Ochoco & Umatilla & Wallowa-Whitman \\
\hline 2006 & 0 & 2 & 0 & 0 & 0 & 2 \\
\hline 2007 & 0 & 2 & 0 & 0 & 0 & 3 \\
\hline 2008 & 2 & 2 & 0 & 1 & 0 & 0 \\
\hline 2009 & 1 & 2 & 1 & 0 & 0 & \\
\hline 2010 & 1 & 1 & 2 & 0 & 0 & 0 \\
\hline 2011 & 0 & 0 & 2 & 0 & 0 & \\
\hline 2012 & 0 & 0 & & & \\
\hline
\end{tabular}


Number of timber sale and fuel treatment NEPA documents per Forest Collaborative Group per year.

\begin{tabular}{|l|l|l|l|l|l|}
\hline Year & BMFP & COPWRR & HCRC & LSG & WCNRAC \\
\hline 2006 & 0 & 0 & 0 & 2 & 2 \\
\hline 2007 & 0 & 0 & 0 & 2 & 3 \\
\hline 2008 & 0 & 3 & 0 & 2 & 2 \\
\hline 2009 & 1 & 1 & 0 & 2 & 3 \\
\hline 2010 & 1 & 1 & 1 & 1 & 0 \\
\hline 2011 & 0 & 0 & 0 & 0 & \\
\hline 2012 & 1 & 0 & 1 & 0 & \\
\hline
\end{tabular}




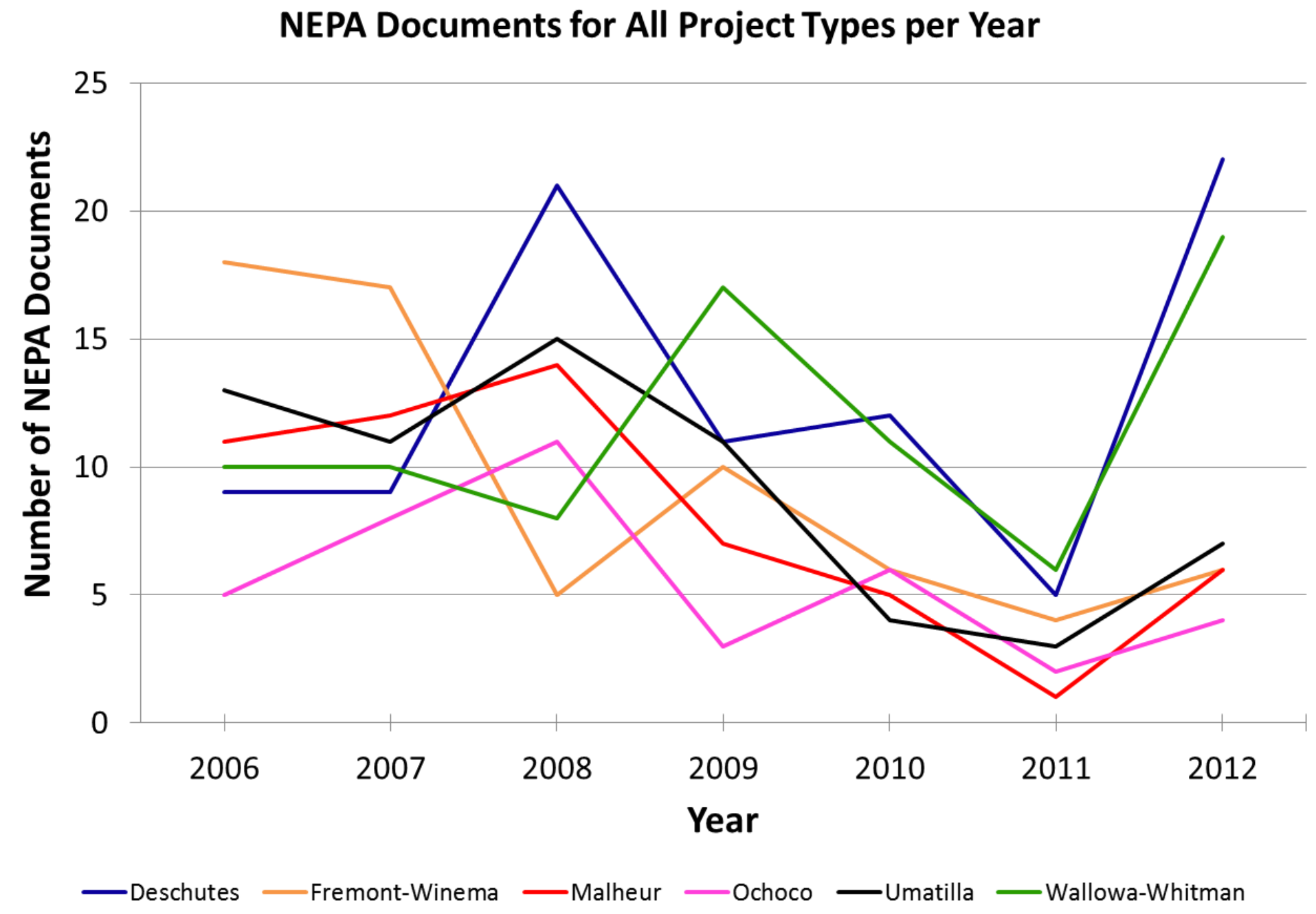

Total number of NEPA documents for all project types for each National Forest from 2006 to 2012. 


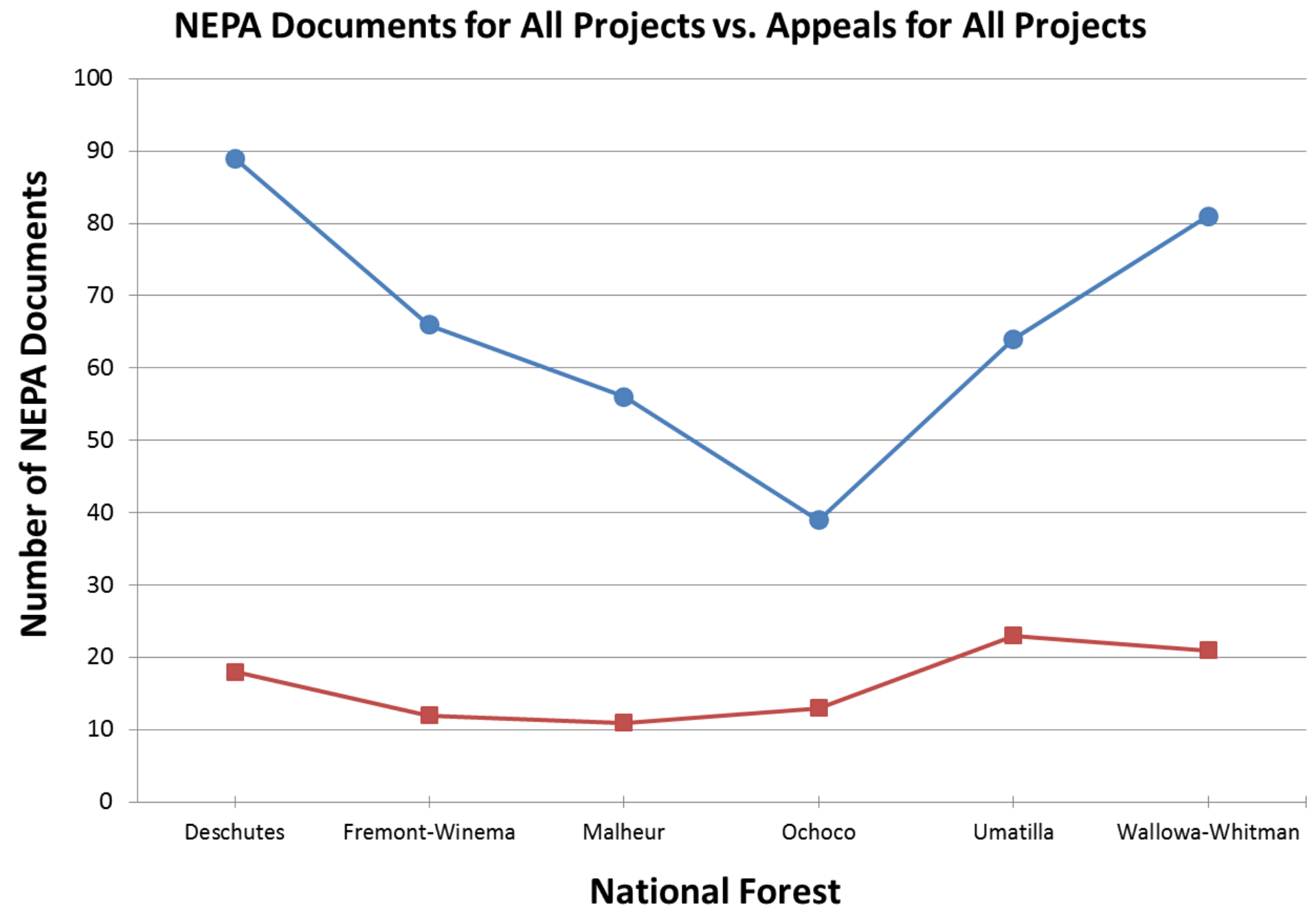

Total number of NEPA documents for all project types (blue line, circles) and appeals and objections for all project types (red line, squares) per National Forest from 2006 to 2012. 


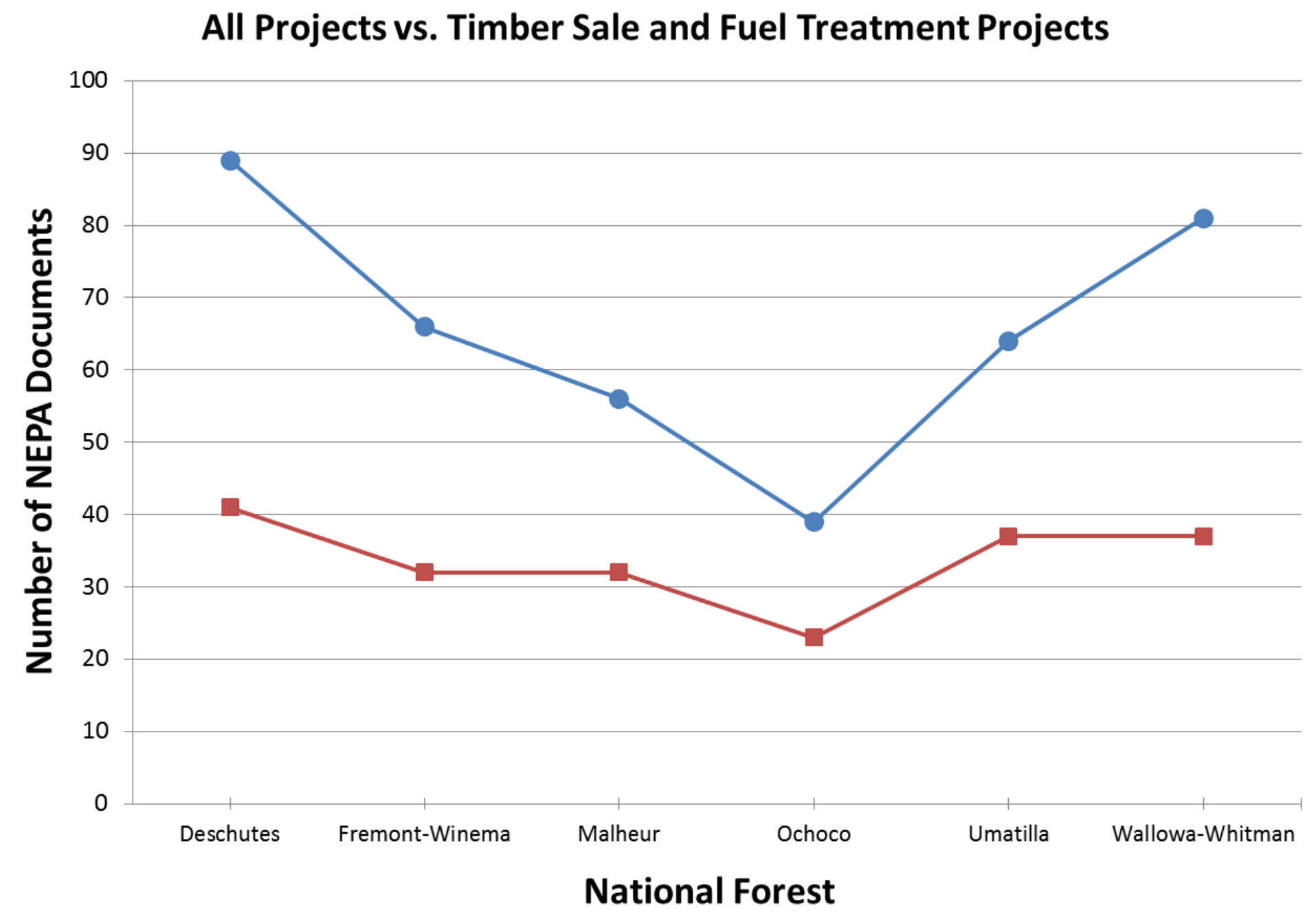

Total number of NEPA documents for all project types (blue line, circles) and only timber sale and fuel treatment project types (red line, squares) per National Forest from 2006 to 2012. 


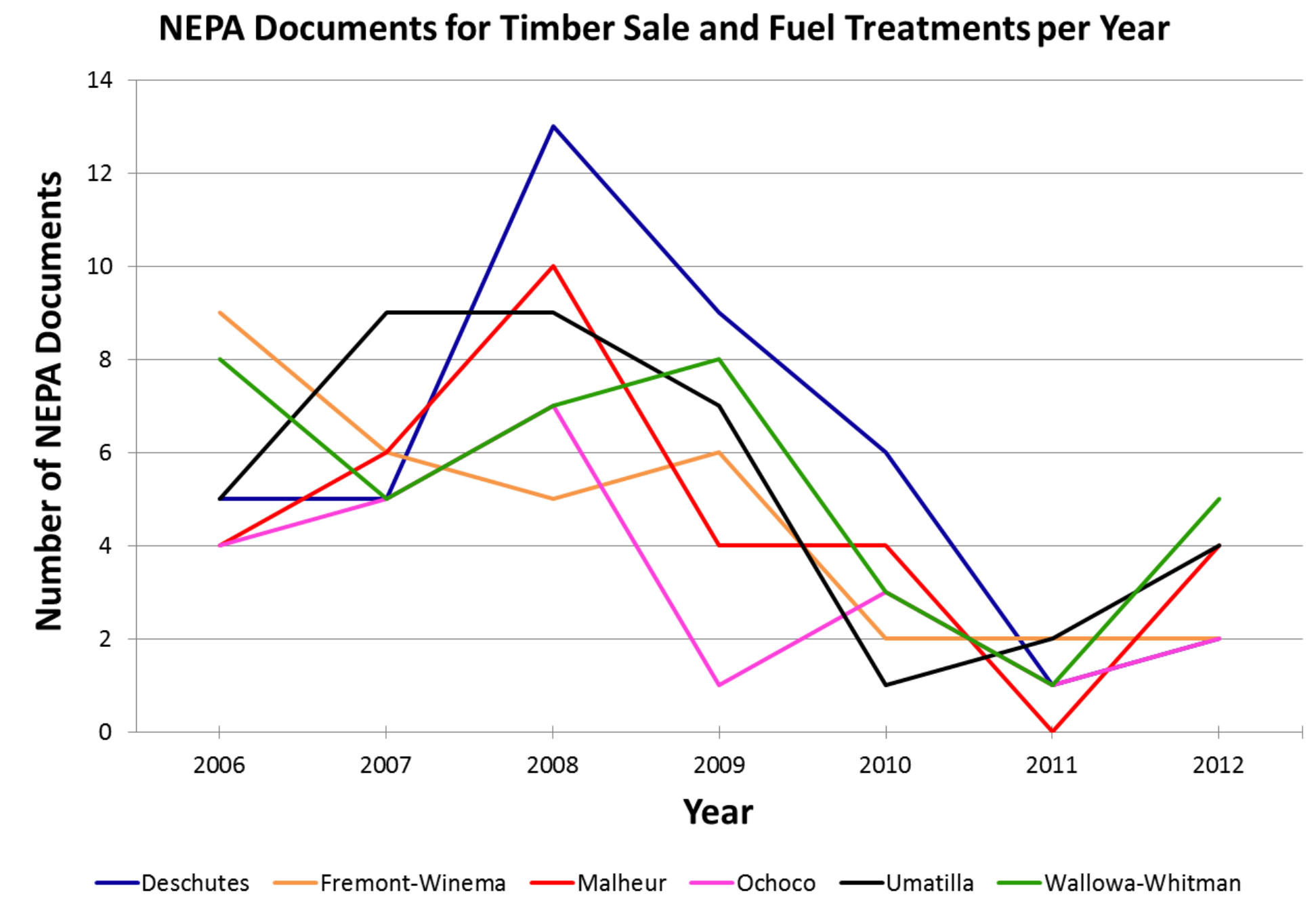

Number of NEPA documents for timber sale and fuel treatment project types for each National Forest per year from 2006 to 2012. 
Timber Sale and Fuel Treatment Projects vs. Number Appealed

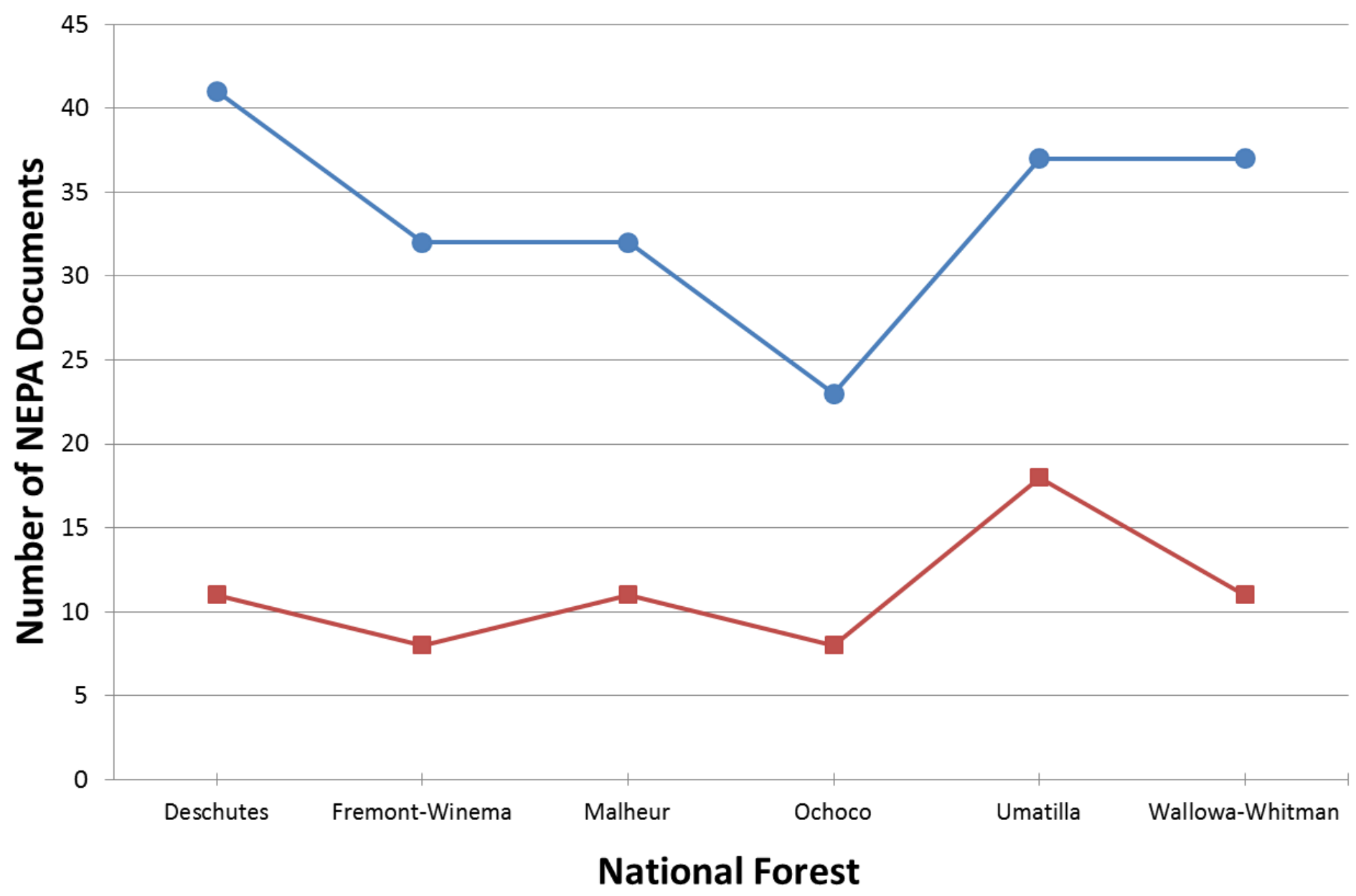

Number of NEPA documents for timber sale and fuel treatment project types (blue line, circles) and number of appeals and objections for timber sale and fuel treatment project types (red line, squares). 
All Project Appeals vs. Timber Sale and Fuel Treatment Appeals

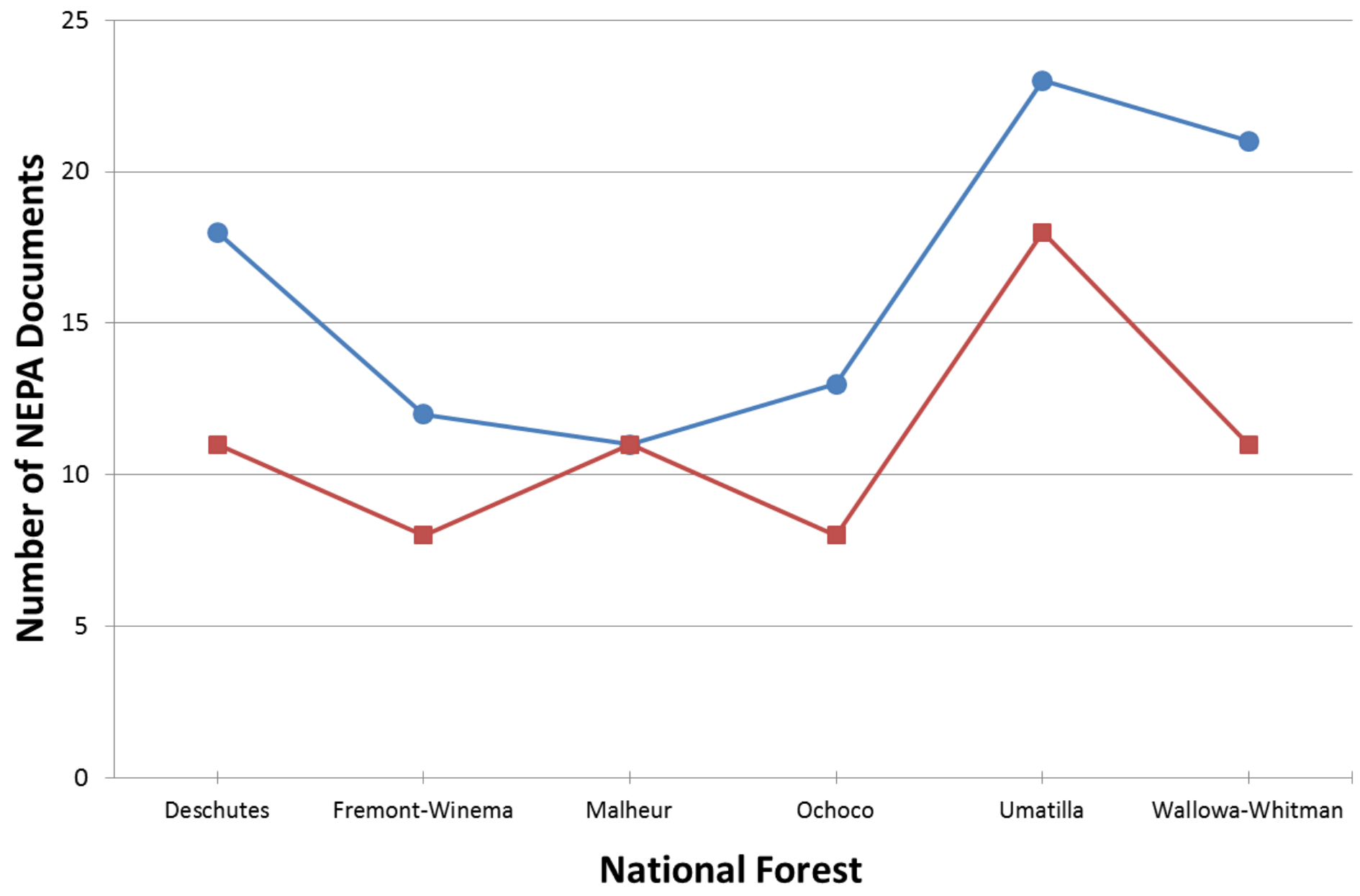

Number of NEPA documents appealed and objected for all project types (blue line, circles) and only timber sale and fuel treatment project types (red line, squares) per National Forest. 


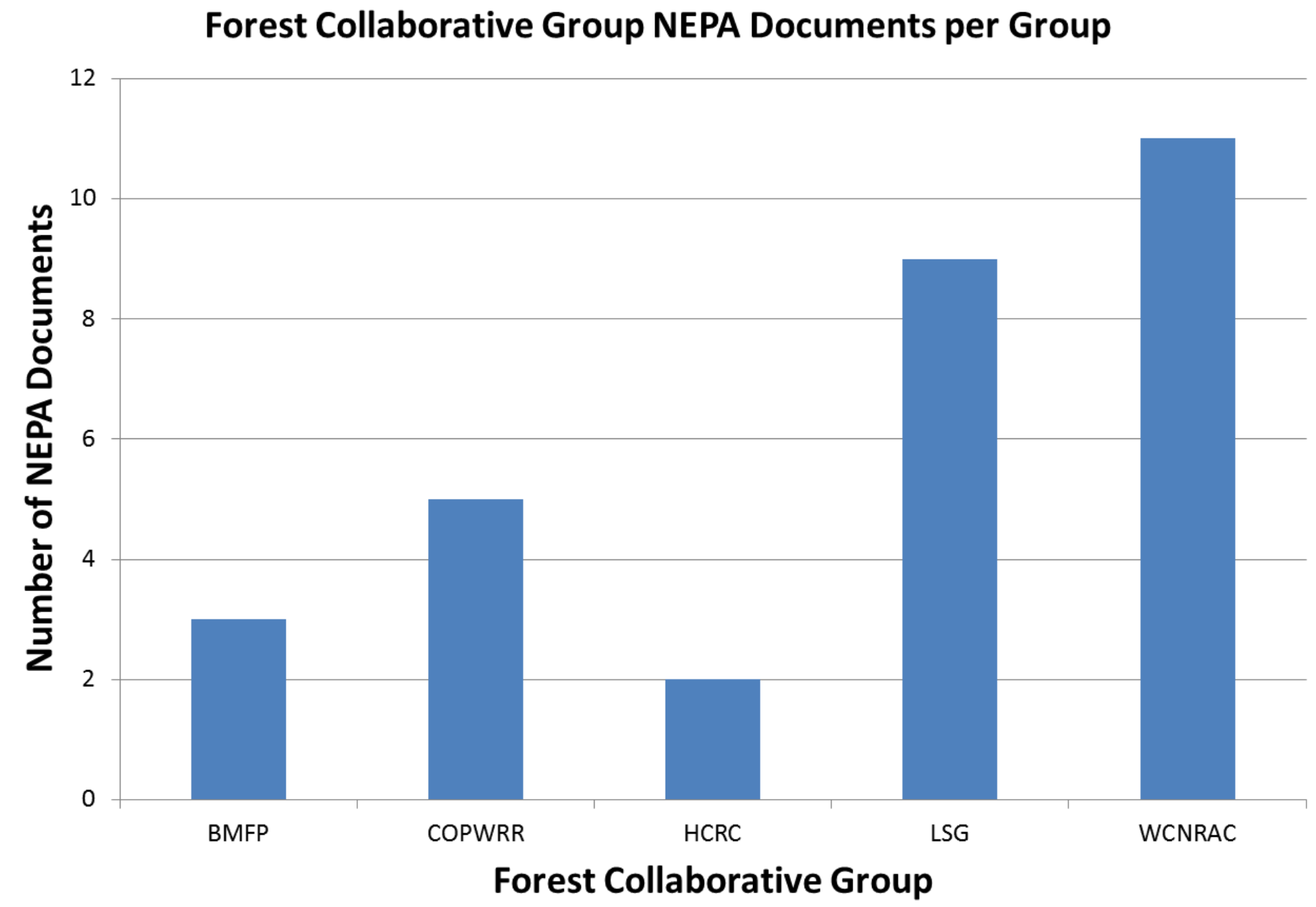

Number of timber sale and fuel treatment NEPA documents per Forest Collaborative Group. Only five of the ten Forest Collaborative Groups in eastern Oregon participated in the NEPA process from 2006 to 2012. See Table 1 for Forest Collaborative Group information. 


\section{Appealed vs. Not Appealed Forest Collaborative Group NEPA Documents}

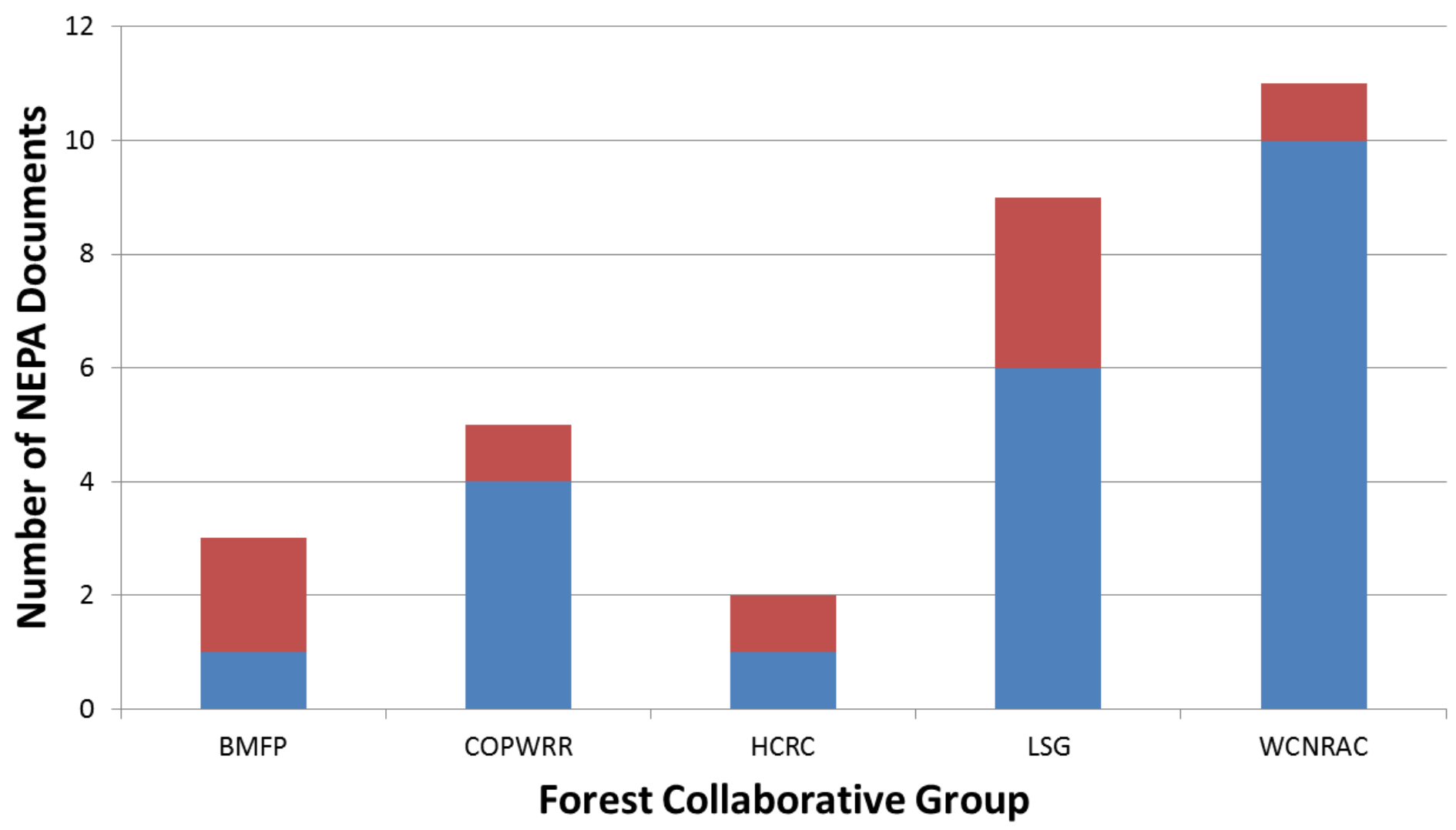

not Appealed/Objected $\quad$ Appealed/Objected

Number of timber sale and fuel treatment NEPA documents per Forest Collaborative Group that were not appealed/objected (blue) versus the number of timber sale and fuel treatment NEPA documents that were appealed/objected (red). 


\section{Forest Collaborative Group Documents vs. Number Appealed}

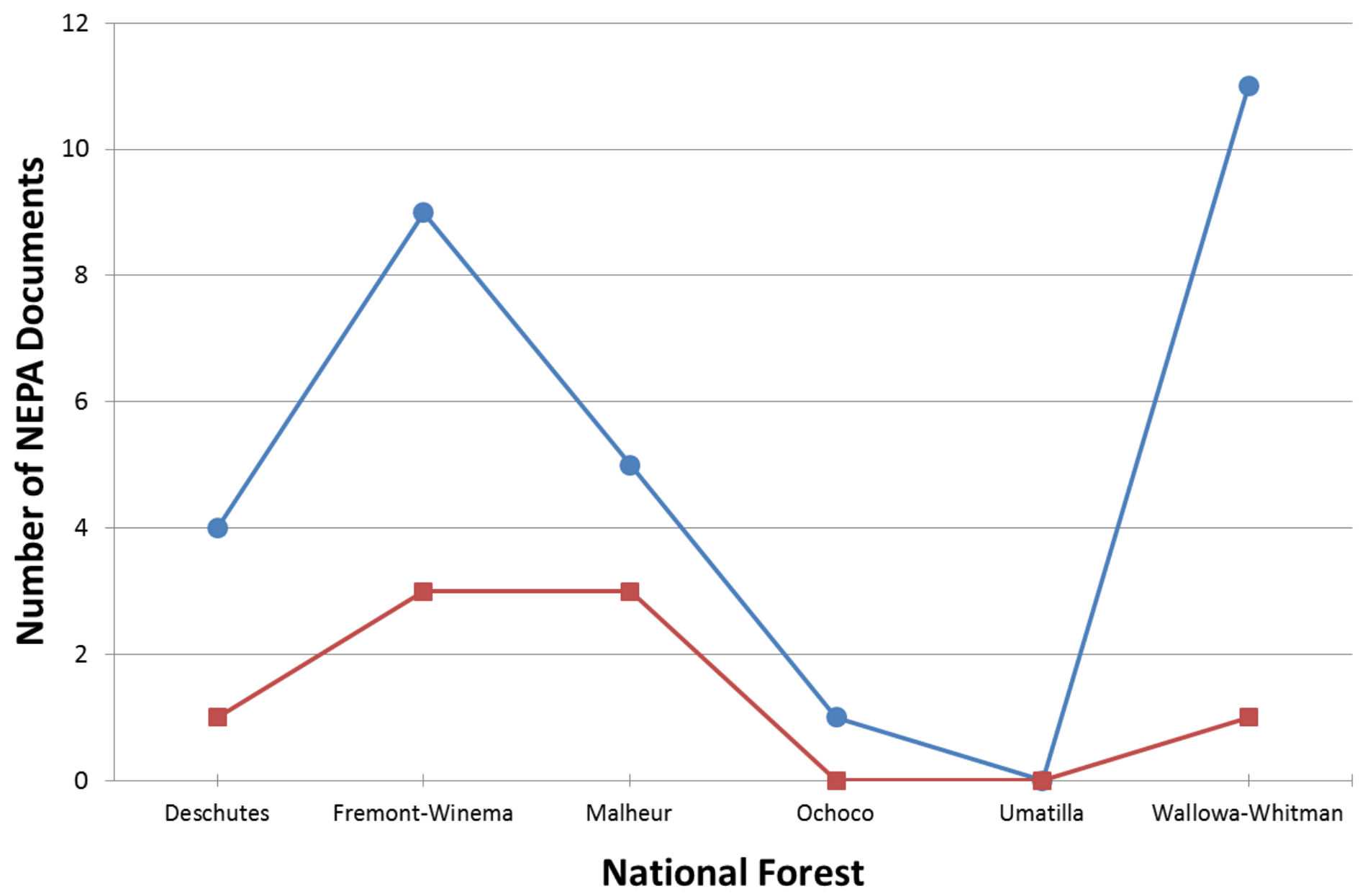

Total number of collaborative NEPA documents (blue) and number of NEPA documents appealed/objected (red) per National Forest from 2006 to 2012. 